\title{
Microbial Responses to Different Operating Practices for Biogas Production Systems
}

\author{
Maria Westerholm and Anna Schnürer
}

\begin{abstract}
Biogas production requires a number of different microbial groups that work in a synchronized and closely interacting manner. For bioreactors constructed to maximize waste treatment and energy production, it is crucial to manage this process in a way that secures the growth and activity of these microorganisms, as otherwise there is a great risk of process failure. However, the microbiome has a remarkable ability to adapt to various conditions related to substrate composition and operating conditions, thus showing high functional redundancy and robustness. In order to optimize and steer the process, it is important to have an understanding of the anaerobic microbiome, how it responds to various conditions, and its upper limits. This chapter reviews current knowledge regarding microbial responses to different operational management strategies. Microbial responses under various conditions and how the process can be operated to maintain the activity of key species are addressed. Parameters discussed include for example substrate composition, pretreatment, ammonia level, temperature and organic load.
\end{abstract}

Keywords: anaerobic degradation, microbiology, taxonomy, start-up, temperature, substrate composition, feeding, additives, bioaugmentation

\section{Introduction}

As the world's population continues to grow, it is necessary to find ways to develop resourceful waste treatment methods while concurrently reducing the dependency on fossil fuels. In this regard, biogas produced through anaerobic degradation $(\mathrm{AD})$ is highly interesting, as it can replace fossil fuels in power and heat production, be used as feedstock for production of biochemicals, or be converted to vehicle fuel [1]. The biogas technology also enables resource sustainability when the digestion residue (digestate) is used as organic fertilizer to replace fossil energyrequiring mineral fertilizers [2].

Anaerobic digestion of organic material to biogas is a complex microbiological process requiring the combined activity of several groups of microorganisms with different metabolic capacities and growth requirements. To obtain a stable and efficient biogas process, it is important to meet the growth requirements of all microorganisms involved. The substrate is one critical parameter in this regard, contributing growth factors and macro- and micronutrients. Some organic materials can be used as the sole substrate, while others have to be co-digested with 
substrates that are complementary in composition in order to provide favorable conditions for microbial growth [3]. However, addition of additives such as iron, trace metals, or buffering chemicals may be essential in certain processes in order to ensure sufficient microbial activity and to prevent process collapse [4]. In addition to the nutrient composition, operating parameters such as pretreatment method, load of input material, retention time, process temperature, and stirring are of critical importance. All these parameters have to be set at appropriate levels in order to ensure high activity and gas yield with minimized risk of inhibition or washout of critical functions and microorganisms [5-9]. Thus, many different aspects need to be taken into consideration to achieve optimal microbial activity giving a high degree of degradation and gas production. It should be borne in mind that many operating and biological parameters are interlinked, sometimes with counteracting effects.

\section{Characteristics of substrates used for biogas production}

The composition of substrates can vary considerably between anaerobic digesters, which bring different challenges depending on the feed characteristics combined with the parameters chosen for the specific system. For example, substrates rich in protein and fat have a high energy content and thus a high methane potential, but can sometimes cause process disturbances due to formation of inhibitory compounds or foaming [10-12]. Other materials posing a lower risk of process disturbance, such as lignocellulosic materials, can require an unfeasibly long time for degradation. In order to explain the prerequisites for microbial degradation and the challenges that exist, this section briefly describes the main characteristics of common substrates for biogas production. This provides background for a detailed description of the microbial degradation process and the responses to changes in operating parameters.

Plant-based materials, such as fruit, grains, vegetables, and root crops, are typically rich in different polysaccharides. Polysaccharides are chains of sugars linked in linear chains (cellulose and starch) or branched chains (hemicellulose, pectin, and glycogen). In the plant cell wall, hemicellulose, cellulose, and lignin are associated in the form of lignocellulose [13]. Simple polysaccharides such as starch and glycogen are easily cleaved by microorganisms into glucose units. Hemicellulose and cellulose are also relatively easily degraded but, when combined with lignin (i.e., lignocellulose) as in plants, the structure becomes relatively persistent to microbial degradation $[14,15]$. Lignocellulosic materials such as straw (wheat, rice, corn, barley) and sugarcane bagasse are the most abundant renewable biomass and have high potential to contribute to expansion of worldwide biogas production $[13,16]$.

Protein-rich materials for biogas production include waste from animal rearing (slaughterhouse, dairy, animal manure, aquaculture sludge), ethanol fermentation (distiller's waste), food industry, and households [10, 17-21]. Proteins consist of long chains of amino acids joined by peptide (or amide) bonds and there are 20 different amino acids of various lengths. A feature of all amino acids is that they have at least one amine group $\left(-\mathrm{NH}_{2}\right)$. The efficiency of protein degradation depends on the structure of these compounds and their solubility [22].

Slaughterhouse waste, food waste, and grease-separation sludge are materials with a high fat content [23-25]. Fat molecules are of different lengths (saturated or unsaturated) and are hydrolyzed to long-chain fatty acids (LCFA, >12 carbon atoms) and glycerol [26]. Lipids are normally rapidly degraded in $\mathrm{AD}$, whereas the conversion of LCFA can represent a rate-limiting step [27, 28]. 


\section{The microbial degradation steps leading to methane}

The microbial process comprises the main degradation steps hydrolysis, acidogenesis, acetogenesis, and methanogenesis (Figure 1) and this process has to be efficient and balanced in order to obtain successful anaerobic digestion. The initial step is performed by hydrolytic bacteria, and possibly also fungi, that convert polymers (polysaccharides, lipids, proteins, etc.) into soluble monomers (LCFA, glycerol, amino acids, sugars, etc.) $[29,30]$. The hydrolytic reaction is mediated by extracellular enzymes secreted by bacteria to the bulk solution and/or attached to their cell wall. Cellulose is hydrolyzed to cellobiose and glucose, while hemicelluloses are degraded to monomeric sugars and acetic acid by bacteria that often have several different enzymes combined into so-called cellulosomes situated on their cell wall [16, 31]. These cellulosomes contain proteins that have the ability to bind to cellulose, which makes the degradation more efficient because the enzymes can work directly "on-site." Fungal cellulases use a different mechanism and not only bind to the surface of the cellulose, but also to penetrate inside the complex biomass materials (e.g., plant cell walls) [32].

Through the action of extracellular enzymes (proteases), proteins are hydrolyzed into amino acids, which are subsequently degraded in the Stickland reaction or through uncoupled oxidation. In the Stickland reaction, one amino acid acts as an electron donor and the other as an electron acceptor, and the oxidation process produces a volatile carboxylic acid that is one carbon atom shorter than the original amino acid. For example, alanine with its three-carbon chain is converted to acetate [33]. Amino acids can also be fermented through uncoupled oxidation where electrons are instead released as hydrogen. This process can only occur in cooperation with a hydrogen-utilizing partner, such as methanogens, that keeps the hydrogen partial pressure low [34]. Irrespective of the degradation pathway, the amino group in the amino acid is released as ammonia and the sulfur in cysteine and methionine results in sulfide. Lipases are excreted by hydrolytic bacteria and catalyze the hydrolysis of lipids at the water-lipid interface [35], forming saturated or unsaturated LCFA and glycerol [36]. LCFAs thereafter absorb to and are transported through microbial

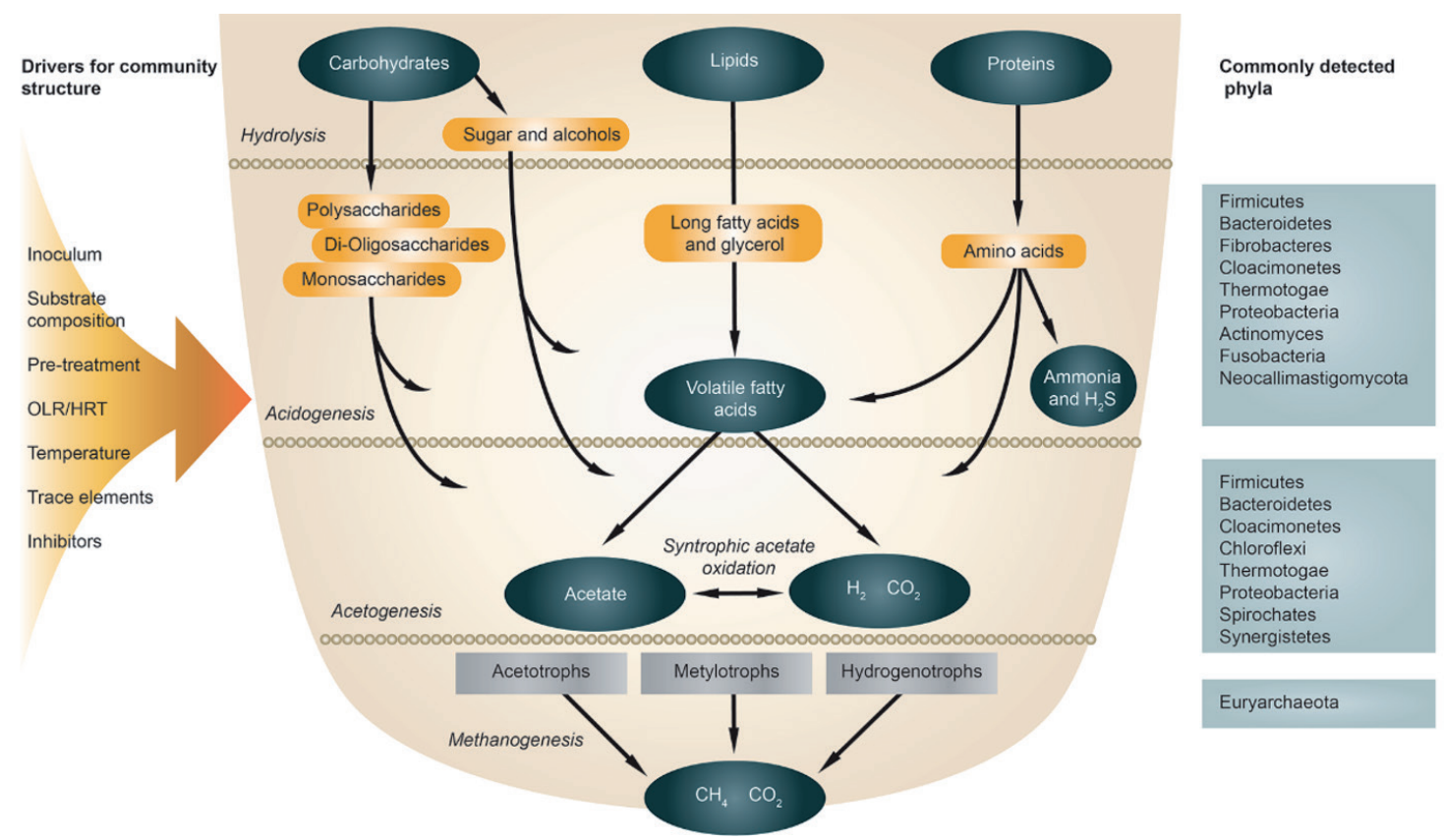

Figure 1.

Anaerobic degradation of carbohydrates, lipids, and proteins and the phyla commonly reported to be involved in the different steps. Biogas digester parameters identified as main drivers for community structure is depicted. The figure is adapted from Kougias et al. [39]. 
cell membranes of acetogenic bacteria, where the LCFAs are converted to acetate via beta-oxidation to acetate, carbon dioxide $\left(\mathrm{CO}_{2}\right)$, and hydrogen $\left(\mathrm{H}_{2}\right)[37,38]$.

The soluble monomers produced in the hydrolytic and acidogenic steps are further degraded to intermediate products. These mainly comprise volatile fatty acids (e.g., acetate, propionate, butyrate, lactate, valerate, and caproate), alcohols, formate, $\mathrm{H}_{2}$, and $\mathrm{CO}_{2}$ [40]. During acetogenesis, the products formed in hydrolysis/acidogenesis are further converted by a group of bacteria called acetogens, generating acetate, $\mathrm{H}_{2}$, and $\mathrm{CO}_{2}$ as main products. During this process, various electron acceptors can be used, including $\mathrm{CO}_{2}$, nitrate, sulfate, and protons, with the latter being most important in the biogas process [41]. Acetogens can also directly use products from hydrolysis, such as sugars and amino acids [42], or oxidize pyruvate, which is a common intermediate in anaerobic degradation reactions, to acetate [43]. For thermodynamic reasons, many reactions performed by acetogens, such as oxidation of organic acids and LCFA, can only proceed if the partial pressure of $\mathrm{H}_{2}\left(p_{\mathrm{H} 2}\right)$ is kept low [44]. For some acids, such as propionate, the removal of acetate can also be of crucial importance [45]. The removal of the acidogenic products acetate and $\mathrm{H}_{2}$ /formate and some methylated compounds mainly proceeds through consumption by methanogens. The energetic situation for the methanogens is comparatively more favorable than acetogenesis, and thus combining these reactions allows both organisms to obtain energy for growth. This type of symbiosis, in which neither organism can operate without the other but together they exhibit metabolic activities that they could not accomplish on their own, is called syntrophy $[43,44]$.

In the last step, methanogenic archaea use acetate, $\mathrm{CO}_{2}$, or methylated compounds to produce methane $\left(\mathrm{CH}_{4}\right)$ (Figure 1$)$. In acetate-utilizing (aceticlastic) methanogenesis, acetate is split into a methyl group and $\mathrm{CO}_{2}$, and the methyl group is later reduced to methane using an electron provided by the carboxyl group. $\mathrm{CO}_{2}$ is reduced to methane by hydrogenotrophic methanogens, using $\mathrm{H}_{2}$ or formate as primary electron donors. In methanogenesis from methylated compounds such as methanol, methylamines, and methylsulfides, the methyl group is reduced to methane. Most methylotrophic methanogens then obtain the electrons they require for reduction from oxidation of additional methyl groups to $\mathrm{CO}_{2}[46,47]$.

\section{Microorganisms engaged in the different degradation steps}

Organisms that are active during the hydrolysis of polysaccharides in biogas processes include various bacteria and anaerobic fungi [14,29]. Cellulose and starch-degrading bacteria are found within the genera Acetivibrio, Butyrivibrio, Caldanaerobacter, Caldicellulosiruptor, Clostridium, Eubacterium, Halocella, Ruminoclostridium and Ruminococcus (phylum Firmicutes), Bacteroides and Paludibacter (phylum Bacteroidetes), Fibrobacter (phylum Fibrobacteres), Spirochaetes (phylum Spirochaeta), and Fervidobacterium and Thermotoga (phylum Thermotogae) [14, 48-57]. Identification of the genes necessary for degradation of cellulose has also led to the suggestion that members of the phylum Proteobacteria [56], candidate phylum Cloacimonetes [58] and Actinomyces [59] have this ability. Among the anaerobic fungi, representatives of the phylum Neocallimastigomycota, commonly also found in ruminants, have been suggested as promising candidates to improve biogas production from lignocellulosic material $[60,61]$. Protein and amino acid degradation in anaerobic digesters has been shown to be performed by various genera within the phylum Firmicutes, such as Anaeromusa, Anaerosphaera, Aminobacterium, Aminomonas, Gelria, Peptoniphilus, 
Thermanaerovibrio [62-67], Clostridium [68], Proteiniborus [69], and Sporanaerobacter [70]. However, members of the phyla Bacteroidetes (e.g., genera Fermentimonas and Proteiniphilum), Fusobacteria, and Cloacimonetes have also been suggested to have an active amino acid-based metabolism in anaerobic digesters $[71,72]$. Less is known about bacteria involved in hydrolysis of fat. Lipolytic bacteria in anaerobic digesters has so far been proposed to belong to families Caldilineaceae (phylum Firmicutes), Bacteroidaceae (phylum Bacteroidetes) and to genera Trichococcus (phylum Firmicutes), Devosia, and Psycrobacter (phylum Proteobacteria) [73, 74].

Acetogenesis and syntrophic acid degradation are often performed by bacteria belonging to the genera Clostridium and Acetobacterium (phylum Firmicutes), but have also been assigned to the phylum Proteobacteria [14, 43, 75]. Bacteria identified so far that are capable of $\beta$-oxidizing LCFA in syntrophy with methanogens all belong to the families Syntrophomonadaceae and Syntrophaceae [23, 76]. Syntrophs that degrade short-chain fatty acids, such as butyrate, propionate, and acetate, in association with methanogens are phylogenetically distributed. Syntrophic propionate and butyrate degradation is performed by genera such as Syntrophomonas, Syntrophospora, Syntrophothermus, Thermosyntropha, and Pelotomaculum (phylum Firmicutes), or the genera Syntrophus, Smithella, and Syntrophobacter (phylum Proteobacteria) [77]. In addition, the phyla Cloacimonetes, Synergistetes, and Chloriflexi have been suggested to contain bacteria capable of performing syntrophic metabolism in association with hydrogenotrophic methanogens [78-80]. Bacteria capable of syntrophic acetate oxidation identified to date belong to the genera Clostridium, Thermoacetogenium, Syntrophaceticus, and Tepidanaerobacter (phylum Firmicutes) [81]. Novel syntrophic acetate-oxidizing bacteria (SAOB) candidates have been suggested within the order Clostridiales and/or Thermoanaerobacterales [82-86], Synergistes group 4 [87], the genus Coprothermobacter [88] and the phyla Spirochaetes [89], Thermotogae [83], Chloroflexi, and Bacteroidetes [90].

In terms of relative abundance, the methanogenic community generally represents a minor part (2-5\%) of the total community, but methanogens have been observed to have high activity relative to their abundance [83, 91, 92]. Methanogens commonly detected in biogas digesters belong to the orders Methanobacteriales, Methanomicrobiales, and Methanosarcinales (phylum Euryarchaeota). However, the orders Methanococcales and Methanomassiliicoccales (phylum Euryarchaeota) have also been found in AD systems [30, 93]. Hydrogenotrophs are found within all methanogenic orders except for the Methanomassiliicoccales [93]. Acetate is only used by members of the families Methanosarcinaceae and Methanosaetaceae (order Methanosarcinales). Members of the Methanosarcinaceae are comparatively more versatile, having the ability to grow on several different substrates, such as acetate, hydrogen, and methanol, while members of the Methanosaetaceae use only acetate [94]. Methane formation from methylated compounds is performed by members of the Methanomassiliicoccales, Methanobacteriales, and Methanosarcinales [93]. A candidate methanogenic class, WSA2, has also been proposed and suggested to be restricted to methanogenesis through methylated thiol reduction [95].

With ongoing advances in molecular techniques and cultivation studies, the list of anaerobic microorganisms responsible for different degradation pathways is continually being updated. The complexity of the cooperation involved in degradation is further illustrated by the fact that members within one and the same genus are often able degrade chemically different compounds. In future, the introduction of omics approaches, combined with isolates of novel species, will most likely increase insights into the taxa involved [30, 96-99]. 


\section{The impact of different operating conditions on AD microbial communities}

To optimize the anaerobic digestion process and steer it in a desired direction, it is important to have knowledge and understanding of the metabolic capacities of key microorganisms. Knowledge of the level of functional redundancy within the community (how easily the microbial community adapts to operating changes) and microbial requirements for activity can also help identify operating management practices for improved process performance. In this section, the impact on the microbial community of different operating strategies is described.

\subsection{Start-up strategies}

The inoculum used for starting up a biogas process has been shown to be of importance for the degradation rate, specific methane yield, and stress tolerance, possibly depending on differences in the composition of the microbial community [52, 100-104]. In addition, chemical parameters, such as presence of trace elements needed for microbial activity, have been suggested to be important [105]. Inocula, most commonly applied in practice, can be categorized as originating from one of the following three sources: wastewater treatment plants, agricultural biogas plants, and plants treating various biowastes, such as municipal and industrial food waste [101]. Microbial analyses of biogas plants belonging to these different groups have clearly shown separation based on microbial community structure [102, 103, $106,107]$. This separation is believed to be caused by the substrate characteristics and operating conditions, with temperature and ammonia being strong regulating parameters [106]. It has been suggested that wastewater sludge is most optimal as the inoculum for biomethane potential (BMP) tests, due to its diverse and highly active community [101]. However, Koch et al. [108] found that inoculum originating from a plant degrading similar substrate to that evaluated in the BMP test gave the best results, suggesting that a substrate-adjusted microbial community is more suitable. Choosing inoculum from a well-functioning biogas process degrading similar substrate and operating under the parameters planned for the new process has also been shown to reduce the period for start-up and avoid initial instability during continuous operation $[52,100]$. It has been suggested that methanogenic activity and abundance are appropriate parameters for assessing the suitability of an inoculum and for achieving high rates and yields in BMP tests, as well as for operation of a continuous biogas process $[100,109]$. Another factor that can be favorable for the process is to use an inoculum with high microbial diversity, which is considered to correlate with high functional redundancy. One hypothesis to explain this is that having a large number of species provides potential for failing species to be easily replaced by other species performing similar functions, with little impact on the overall process [110].

Evaluations of different inocula during semi-continuous operation using the same substrate have been made for mesophilic processes operating with maize silage [103], a mix of manure and grass [52], cellulose [102], and a mix of waste-activated sludge and glycerol [100]. These studies have produced some contradictory results with regard to the composition of the microbial community over time. Han et al. [102] found that the inoculum source was determining for methane yield, $\mathrm{pH}$, and volatile fatty acid (VFA) production using cellulose as a substrate, both during start-up and after reaching stable operation. Different steady state community patterns were also obtained in the different reactors started with different inocula. Moreover, reactors characterized by high VFA levels and low $\mathrm{pH}$ had comparatively 
low levels of Methanosarcinales, highlighting the importance of this methanogen for efficient biogas production. In line with this, high levels of Methanosarcinales have also been shown to be important for efficient start-up and revival of a thermophilic process suffering from high acetate levels [111]. In contradiction to the results reported by Han et al. [102], a study employing three different inocula for start-up of parallel processes using a manure-grass mix as substrate found that the overall microbial community and process performance became similar in the parallel processes after three hydraulic retention times (HRT) of operation [52]. However, a clear difference in performance was seen during the initial phase after start-up in that study, with poor performance when using an inoculum from a high-ammonia process. Less efficient start-up using a high-ammonia inoculum was also seen in a study by de Vrieze et al. [100] on AD with sludge and glycerol. High-ammonia levels usually impact microbial richness and cause significant shifts in both the bacterial and methanogenic community $[82,106]$. This possibly explains the less efficient start-up performance when using substrate with a comparatively low nitrogen level [100]. A negative correlation between ammonia level and cellulose degradation efficiency was also found in the abovementioned study by Liu et al. [52]. Interestingly, when processes started with different inocula and unified in performance and microbial community were supplemented with an additional substrate in that study, the processes again diverged in both performance and microbiology. These results illustrate that choice of inoculum can influence long-term performance of biogas processes [112]. Moreover, even when the same inoculum and operating parameters are used during start-up, different process performances and microbial communities can evolve $[102,113]$. This illustrates that stochastic factors play an important role in the microbial community assembly in biogas reactors. It also highlights the need for further research on the impact of inoculum source and operating conditions on long-term effects and optimized performance.

\subsection{Temperature}

Temperature strongly affects the microbial community structure and thus also process performance and stability $[5,92,106,107,114-118]$. When choosing the operating temperature, other operating parameters such as substrate, feeding strategy, and presence or possible formation of inhibitory compounds should be taken into account. The temperatures normally used for digestion in industrial biogas processes are not only mesophilic $\left(37-40^{\circ} \mathrm{C}\right)$ or thermophilic $\left(50-55^{\circ} \mathrm{C}\right)$, but also psychrophilic $\left(<25^{\circ} \mathrm{C}\right)$ and temperatures between mesophilic and thermophilic $\left(41-45^{\circ} \mathrm{C}\right)$ have been shown to be achievable [57, 118-122]. Some studies investigating $\mathrm{AD}$ at $41-45^{\circ} \mathrm{C}$ have even reported higher methane production compared with the more commonly used mesophilic or thermophilic range, with associated microbial shifts [57, 119, 121]. In general, metabolic rates and biochemical processes increase with increasing temperature $[115,123,124]$. However, thermophilic conditions can also make the process more sensitive to disturbances and inhibitory compounds [115, 125] and cause less efficient degradation of some inhibitory compounds [126]. Shifts in microbial community in response to temperature change can take time and involve periods of instability. It is therefore recommended to allow the community to adapt to the temperature change by a slow increase/decrease $\left( \pm 1^{\circ} \mathrm{C}\right.$ per day) $[5,127-130]$. In order to avoid process collapse, temperature changes should be carefully monitored, both when increasing and decreasing the operating temperature. A temporary reduction in feed rate and prolonged retention time can be required in the event of disturbance during step-wise temperature changes [5]. Another important aspect to consider during AD operation is that the microbial community, specifically the methanogens, is sensitive to long-term 
temperature variations. Experience from large-scale operations shows that constant temperature fluctuations should not exceed $\pm 2-3^{\circ} \mathrm{C}$ in order to avoid instability [131].

One quite consistent effect of operation at thermophilic instead of mesophilic temperature is a higher level of Firmicutes compared with Bacteroidetes/ Proteobacteria [5, 57, 116, 118, 121, 132-136]. A high Firmicutes to Bacteroidetes ratio in mesophilic $\mathrm{AD}$ has been shown to correlate positively with high methane yield $[137,138]$. However, an increase in this ratio has also been suggested to decrease the richness of predicted lignocellulolytic enzymes in biogas digesters, an effect attributed to lower hydrolysis in comparison with natural anaerobic systems [139]. Whether similar correlations arise in comparisons between mesophilic and thermophilic biogas communities has yet to be determined. Another characteristic feature of thermophilic communities is a higher dominance of the phylum Thermotogae [91, 114, 117, 123, 133, 135, 136, 140-143]. Members of the Thermotogae degrade polysaccharides to ethanol, acetate, $\mathrm{CO}_{2}$, and $\mathrm{H}_{2}$ [72, 144], but can also be involved in degradation of alcohols to $\mathrm{CO}_{2}$ and $\mathrm{H}_{2}$ in syntrophic association with a hydrogen-consuming partner [72, 145].

Another aspect to consider during operation at thermophilic temperature is that ammonia inhibition occurs more quickly at higher temperature, as the equilibrium between ammonium and ammonia shifts towards the latter when the temperature rises [146]. Irrespective of temperature, methanogens performing the last step in $\mathrm{AD}$ are among the least tolerant to ammonia and reduced methane yield, and accumulation of fatty acids is a common consequence of microbial inhibition of this group [81]. Methanogenic community changes related to temperature, often combined with increasing ammonia levels, have been reported to include positive correlations between high temperature and enhanced relative abundance of Methanobacteriales (often Methanothermobacter) and/or Methanomicrobiales (often Methanoculleus) [5, $106,116-118,133,136,140-142,147-150]$. The shift in methanogenic community often also involves a shift in acetate degradation pathway from aceticlastic methanogenesis to syntrophic acetate oxidation (SAO) [81]. However, in AD processes that seldom reach high-ammonia levels, such as AD of wastewater sludge, instant temperature changes without associated instability have been shown to be possible [143, 151, 152].

\subsection{Pretreatment}

Wastes rich in lignocellulose (e.g., forestry by-products, straw) or keratinase (e.g., waste from poultry, meat, and fish industries) and wastewater sludge have significant biogas potential $[15,16,153,154]$. However, the complex floc structures of microbial cells in sewage sludge and the recalcitrant structure of lignocellulose make hydrolysis the rate-limiting step in $\operatorname{AD}$ systems $[16,155,156]$. Pretreatment is a well-proven approach to improve degradation of such waste. Common pretreatment strategies comprise physical (e.g., heat/pressure, irradiation, ultrasonic), chemical (e.g., acids/bases, ozonation, oxidation), and biological (addition of fungi/bacteria/enzymes under aerobic or anaerobic conditions) methods $[16,157]$. The general concept of pretreatment is that it should improve the accessibility of the material to microbial degradation by disrupting the structure, changing the biomass porosity, and reducing the particle size to enhance the surface area that can be attacked. Many studies have investigated the effect on methane yield of pretreatment of various materials and many methods have shown improved process efficiency following pretreatment $[16,157,158]$. However, fewer studies have examined the influence of pretreatment on microbial communities and relationships to the increase in methane yield, and most of the studies performed to date have been on AD of waste-activated sludge, with differing results. For example, during mesophilic AD of sewage sludge, some studies have found no 
responses in the microbial community following thermophilic aerobic digestion or ultrasonic or alkaline pretreatment [159-161]. However, in other studies investigating mesophilic $\mathrm{AD}$ processes, ultrasonic, microwave, and electrokinetic pretreatments have all been shown to increase the relative abundance of Clostridiales (phylum Firmicutes) and Cloacimonetes and decrease the relative abundance of Proteobacteria [162, 163]. Moreover, in mesophilic AD of microalgae biomass, thermal pretreatment has been found to increase the relative abundance of the families Rikenellaceae (phylum Bacteriodetes) and Anaerolineaceae (phylum Chloroflexi) and decrease the relative abundance of the phylum Proteobacteria [164]. Using metatranscriptomic analysis, Xia et al. [165] found that low-frequency ultrasonic treatment of sludge during thermophilic digestion increased the hydrolytic activity of representatives of the phyla Bacteroidetes and Cloacimonetes and increased motility and chemotaxis in members of the phylum Thermotoga. Another noteworthy finding in that study was that, among the bacteria involved in cellulose degradation, members of the order Bacteroidales were more active than members of the Clostridiales. Both these groups contain well-known cellulosedegrading bacteria, but members of the Bacteroidales typically do not possess the cellulosomes often seen in Clostridiales. Xia et al. [165] concluded that lowfrequency ultrasonic pretreatment allows enrichment of a community with high hydrolytic activity without attachment to its substrate.

For substrates other than sludge, Wang et al. [166] reported a weak effect on the microbial community structure during digestion of thermal pretreated distilled grain waste in thermophilic solid AD. Thermal and thermochemical pretreatment approaches are the most commonly used methods for lignocellulosic materials used for bioenergy production purposes [167]. Such methods are often efficient in breaking the carbohydrate polymers to soluble sugars and improving the accessibility of the substrate to microbial degradation, thus increasing the biogas yield. However, these pretreatments can also release inhibitors such as furfural, 5-HMF, vanillin, and other phenolic compounds [167]. Depending on concentration, these lignin-derived compounds have been found to be inhibitory to methanogen and to result in decreased hydrolytic activity, and major shifts have been shown to occur in both archaeal and bacterial populations (see reviews $[167,168]$ ). However, adaptation and degradation of these compounds is possible and is suggested to involve members within the families Syntrophorhabdaceae and Synergistaceae, combined with hydrogenotrophic methanogens [167-169]. For optimized degradation of phenolic compounds, thermophilic pretreatment has been suggested [126].

The combined results from studies performed to date suggest that pretreatment mostly causes minor structural adjustments in the prevailing AD microbial community, but still impacts the activity. It is likely that the effect of pretreatment depends strongly on the prevailing operating conditions (e.g., substrate and temperature) and the activity of the microbial community. It can be anticipated that the response in microbial community structure is also linked to the physical effects of the pretreatment on the substrate. Thus, if the pretreatment enhances the solubilization of all components in the substrate, the impact on community structure will be lower than if the pretreatment increases the solubilization of one particular compound (i.e., proteins, carbohydrates, or lipids).

\subsection{Loading rate and retention time}

The hydraulic retention time (HRT) or solid retention time (SRT), i.e., the average time that the biomass is maintained in the digester, and the organic loading rate (OLR) are of great importance for the microbial community. A short HRT and a high OLR are often desirable in commercial biogas production plants, since they 
allow for high-quantity waste treatment and high biogas production (if the AD can maintain efficiency). However, SRT should exceed the microbial doubling time of prevailing microorganisms, in order to avoid washout of the consortium and thus process collapse. Immobilization of microorganisms through inclusion of support material or by allowing the formation of granular sludge, flocks, or biofilms is a strategy used in high HRT systems to support and maintain organisms with lower growth rate than the solid retention time $[170,171]$.

The response by the microbial community to change in OLR and HRT has been shown to vary depending on operating conditions such as temperature and composition of substrate $[5,6]$. The prevailing microbial community at the time of OLR/ HRT change is also important for the overall response [172]. Moreover, the feeding approach, i.e., continuous or discontinuous feeding, can be determining for community changes [173]. Changes in OLR/HRT have been shown to cause a response in most phyla dominating in $\mathrm{AD}$, such as Actinobacteria, Bacteroidetes, Firmicutes, Chloroflexi, Thermotogae, Cloacimonetes, and Euryarchaeota [172-176].

In the case of increasing load, bacteria associated with hydrolytic and acidogenetic activity, such as members of the Firmicutes or Bacteroidetes, have been shown to be enriched, in parallel with accumulation of accumulation of fatty acids [172, 176-178]. Typically, acetate accumulates first and propionate accumulates if the process disturbance continues, which is assumed to be caused by limited methanogenesis and excess levels of hydrogen $[5,172,179]$. In high-solid mesophilic AD, an increase in OLR has been found to decrease the relative abundance of Firmicutes and increase that of Bacteroidetes and Candidate division WS6 [174]. During increasing OLR of protein-rich waste (blood, casein) in mesophilic AD, the order Thermoanaerobacteriales, harboring several known SAOBs (e.g., Caldanaerobacter and Alkaliphilius), has been shown to increase, while the relative abundance of Bacillus (Bacteroidetes) decreases [10]. In thermophilic AD of lignocellulose, decreasing the retention time from 20 to 3 days has also been shown to increase the levels of Firmicutes, while Thermotogae and Chloroflexi decrease in abundance [175]. During mesophilic AD of food waste at increasing OLR (3-7 g volatile solids $\mathrm{L}^{-1} \mathrm{~d}^{-1}$ ) and HRT (15-20 days), a dynamic succession has been seen in different bacterial phyla (Firmicutes and Actinobacteria), while the abundance of Euryarchaeota, specifically families Methanosarcinaceae and Methanosaetaceae, increases [172].

The frequently reported increase in the genus Methanosarcina in response to increasing OLR has been attributed to its efficient acetate degradation capacity and robustness to stress [94]. Several studies also suggest that members of the Methanosarcina are important for maintained and efficient methane production under increasing OLR $[172,180]$. However, members of the Methanobacteria, Methanomicrobiales, and/or Methanomassiliicoccaceae have also been observed in certain processes with a high load, depending on prevailing conditions $[5,120,176,179$ 181]. During loading by pulsed feeding, the hydrogenotrophic Methanomicrobiales have been shown to increase, favoring the consumption of propionate, most likely through hydrogen utilization. These methanogens have also been detected in highammonia processes operating at high OLR [179]. Ferm et al. [182] and Xu et al. [172] suggest that acetate-utilizing methanogens are critical for efficient methane production during stable performance at increasing OLR. However, with "overload" and acidification, hydrogenotrophic methanogens, such as representatives of the orders Methanomicrobiales and Methanobacteriales, become more important and dominant.

\subsection{Changes in substrate composition and feeding strategies}

Substrate composition is another parameter that strongly impacts the microbial community. It is well-known that co-digestion of different materials often achieves a more balanced nutrient level and improves the process performance and biogas yield 
$[3,183,184]$. However, the substrate availability for a commercial biogas plant may not always be optimal and the availability can also change over time. When changing substrate composition or choosing a substrate for a new $\mathrm{AD}$ process, the estimated energy yield and the nutrient value of the digestate generated have to be balanced against possible problems associated with different substrates, such as ammonia inhibition, acidification, and foaming. This section reviews the microbial communities commonly observed in processes fed with protein-, carbohydrate- or fat-rich material and the microbial responses to operating challenges that often occur in these processes.

\subsubsection{Protein-rich substrate}

Proteins are energy-rich and contribute nutrients to the digestate, but a possible effect of ammonia inhibition has to be considered in the processing. Ammonia $\left(\mathrm{NH}_{3}\right)$ and ammonium $\left(\mathrm{NH}_{4}{ }^{+}\right)$are formed by the microbial degradation of proteins and in particularly the unionized $\mathrm{NH}_{3}$ is toxic to microorganisms [185]. $\mathrm{NH}_{3}$ and $\mathrm{NH}_{4}{ }^{+}$exist in equilibrium and higher temperature and $\mathrm{pH}$ shift the ratio toward a higher level of ammonia. Thus, in addition to the nitrogen content, temperature and $\mathrm{pH}$ should be taken into account in prediction of inhibition following a change in substrate composition [186]. The aceticlastic methanogens (Methanosaeta sp. and certain Methanosarcina sp.) are considered to be most sensitive to ammonia, but if an ammonia-tolerant community is allowed to persist in the digester, the process can cope with substantially higher ammonia levels than an unadapted process [19]. An ammonia-tolerant community often includes methane formation from acetate via SAO [120, 187-193]. In SAO, acetate-oxidizing bacteria and hydrogenotrophic methanogens work in a syntrophic manner to generate methane. Bacteria species currently known to be capable of SAO belong to the genera Thermacetogenium [194], Pseudothermotoga [145, 195], Tepidanaerobacter acetatoxydans [196], Clostridium [197], and Syntrophaceticus [198]. Methanogenic partners in SAO are suggested to be members of the hydrogenotrophic Methanobacteriales and Methanomicrobiales (often the genus Methanoculleus) [81]. Methanosarcina is moderately ammonia-tolerant and can use both the hydrogenotrophic and aceticlastic pathways for methane formation, and can thus possibly act as a hydrogen scavenger in SAO $[81,94]$ or mediate the entire process, i.e., both acetate oxidation and subsequent methanogenesis $[199,200]$. An increased level of protein can also affect degradation steps other than the syntrophic and methanogenic steps. For example, an increased level of protein in $\mathrm{AD}$ of food waste has been demonstrated to increase the abundance of the families Porphyromonadaceae, Actinomytaceae, Lactobacillaceae, and Caldicoprobacteraceae, suggesting their direct or indirect involvement in protein hydrolysis [82]. In AD of animal manure, higher protein content has been shown to increase the genera Desulfotomaculum and Eubacterium [82, 201]. High levels of ammonia have also been shown to be negatively correlated with degradation of cellulose and with some potential cellulose degraders [112].

\subsubsection{Carbohydrate-rich substrate}

Carbohydrate-rich materials are difficult to use in mono-digestion for biogas, since the $\mathrm{C} / \mathrm{N}$ ratio becomes too high for microbial activity. Carbohydrates are thus typically co-digested with more nitrogen-rich materials. However, complex carbohydrates can pose additional challenges, such as low degradability of lignocellulosic materials, while easily accessible carbohydrates undergo fast acidogenesis that can cause acidification $[202,203]$. Animal manure and sludge are commonly used in co-digestion with straw (corn, rice, tobacco, wheat) and in these processes the two orders Clostridiales (phylum Firmicutes) and Bacteroidales (phylum Bacteroidetes) often dominate. However, the phyla Proteobacter, Chloroflexi, and Fibrobacteres also often increase in response 
to addition of lignocellulosic materials, with some variation depending on codigestion material and prevailing environmental conditions [118, 202, 204-208]. The microbial community structure in $\mathrm{AD}$ of rice straw has been shown to be influenced by temperature, with a higher ratio of Firmicutes to Bacteroidetes being reported at higher temperature [208]. In mesophilic AD of rice straw, Bacteroidetes is reported to be the most prevalent group and the abundance is not influenced by increased OLR, whereas the second most abundant Firmicutes decreases slightly [209]. Metagenomic studies have confirmed the involvement of the phyla Proteobacteria, Firmicutes, Chloroflexi, and Bacteroidetes, but also Actinomycetes, in the degradation of lignocellulose by demonstrating the existence of CAZymes (Carbohydrate-Active Enzymes) in consortia adapted to lignocellulosic materials [59, 202].

Interestingly, similar community profiles as described above are often seen in $\mathrm{AD}$ of material containing comparatively high levels of easily accessible carbohydrates. For example, in co-digestion of fruit and vegetable waste with pig manure, the phyla Firmicutes, Bacteroidetes, Chloroflexi, Proteobacteria, and Actinobacteria have been found to dominate, but the numbers of Firmicutes decrease when the fraction of fruit and vegetable waste (with the highest levels of carbohydrates) decreases [210]. In mesophilic $\mathrm{AD}$ of potato and cabbage waste (alone or in combination), members of the phyla Spirochaete, Bacteroidetes, Firmicutes, and Proteobacteria vary in numbers depending on the substrate combination [203]. In a study examining addition of cellulose and xylan to wastewater sludge, it was found that this increased the relative abundance of the bacterial genus Clostridium (phylum Firmicutes), whereas the levels of the bacterial phyla Thermotogae and Bacteroidetes decreased [211]. In thermophilic AD of cattle manure involving addition of easily degraded carbohydrates in the form of glucose, the genus Lactobacillus (class Bacilli) has been shown to increase [201]. The methanogenic communities identified in various studies on carbohydrate-rich material show diverging structures and appear to be primarily shaped by the co-substrate and prevailing environmental conditions. For example, during straw co-digestion with cow manure or digestion of straw alone, Methanosarcina or Methanosaeta often dominate [204-207, 208, 209]. However, with increasing nitrogen level, temperature, OLR, and/or carbohydrate accessibility, the contribution of hydogenotropic methanogenesis increases, involving Methanoculleus, Methanothermobacter, and Methanobacterium [201-203, 208, 209].

\subsubsection{Lipid-rich substrate}

Lipids are energy-rich and different fat-rich substrates are often used to boost biogas production from sewage and manure [212-215]. Degradation of fat results in glycerol and LCFA, with the latter being a known microbial inhibitor [23]. The bacteria Syntrophomonas (family Syntrophomonadaceae) is commonly enriched in mesophilic co-digestion of lipid-rich materials [216-224] and even represents as much as 30-40\% of the total bacterial community during degradation of LCFA [218, 225]. Moreover, it has been reported [218] that pulse feeding of oleate, instead of continuous feeding of oleate, increases the conversion rates of oleate and acetate and induces greater metabolic flexibility within the LCFA-degrading community dominated by Syntrophomonas population [76]. In thermophilic degradation of animal manure, addition of oleate has been shown to increase the relative abundance of the glycerol- and inositol-fermenting Megamonas (phylum Firmicutes) [201], whereas in mesophilic AD increased levels of glycerol/glycerin enrich the phyla Cloacamonas [226] and Thermotogae in AD of wastewater sludge [227] and the genus Trichococcus and family Syntrophomonadaceae in AD of brewery wastewater [228]. Methanoculleus, Methanobacterium, and Methanospirillum have been proposed as important hydrogen-utilizing partners for LCFA-degrading bacteria, whereas Methanosarcina has been suggested to act both 
as a hydrogen and acetate consumer [216, 229, 230]. However, in pulse feeding of oleate, Methanosaeta increases in importance relative to Methanosarcina, along with higher abundance of Methanoculleus compared with Methanobacterium. This was suggested by the authors to be a consequence of higher acetate affinity and tolerance for LCFA by Methanosaeta and higher affinity for hydrogen by Methanoculleus [218]. In another study, an increased level of the hydrogenotrophic Methanoculleus and Methanobrevibacter was linked to increased methane production from oleate, driven by enhanced concentration of sulfide [224]. In addition to aceticlastic methanogensis, acetate degradation has also been shown to proceed via syntrophic acetate oxidation during LCFA conversion, which is likely linked to high-ammonia level [216].

\subsection{Addition of trace elements}

Trace element deficiency can severely limit microbial activity and cause accumulation of fatty acids, process instability and decreased methane yield from food waste [21, 120, 231, 232], slaughterhouse waste [233, 234], crop material [235], stillage [236], and animal manure, when used as a single substrate or as co-substrate $[237,238]$. In this regard, it is important to consider the level of sulfide, which is primarily formed through protein degradation. Sulfide forms complexes with metals, which decreases the bioavailability of trace elements essential for microbial activity [239-241]. In addition, temperature has been suggested to impact nutrient bioavailability and nutrient requirements $[242,243]$. However, the actual impact of different temperatures on the availability of trace metals has yet to be established.

The trace elements such as cobalt, nickel, iron, molybdenum, and tungsten are essential trace elements, especially for acetogenic and methanogenic microorganisms [244-246]. So far, mainly methanogenic abundance has been shown to be influenced by trace element addition in $\mathrm{AD}$, while less is known about the response in the bacterial community. Thus, it is not clear whether the improved degradation of LCFA and VFA with trace element addition is caused solely by improved activity of methanogens or also improved activity of the syntrophic community. Trace elements have demonstrated to have a pronounced effect on the methanogenic community, including increased abundance or predicted stimulatory effects on the genus Methanoculleus [120,247] and increased abundance of the order Methanosarcinales [200] and the genus Methanobrevibacter (order Methanobacteriales), all in mesophilic AD [247]. Methanoculleus has also been proposed to have a more efficient strategy than Methanosarcina for stabilizing its energy balance, and thus can cope more successfully with trace element limitation [248, 249]. Interestingly, despite improved VFA conversion following trace element addition, SAO-dominated AD processes are reported to show no or decreased abundance of the known syntrophic acetate oxidizers S. schinkii, T. acetatoxydanse, and C. ultunense [120, 200].

\subsection{Bioaugmentation}

The approach of adding microorganisms to the anaerobic process is based on the belief that slow degradation is due to the absence or low abundance of efficient populations responsible for the particular degradation step. Bioaugmentation could thus shorten the time of microbial adaptation to certain environmental conditions/ inhibitors and/or improve methane yield from specific substrates. Since the hydrolytic and methanogenic steps generally appear to be bottlenecks in AD systems, bioaugmentation efforts to date have most commonly been directed at enhancing these two steps. However, bioaugmentation has also been evaluated for improving the transition to psychrophilic temperature, to overcome inhibition of ammonia and reduce the time following overload [250]. 
For the degradation of lignocellulosic material in the biogas process, bioaugmentation with cellulose-degrading bacteria, hydrolytic enzymes, and anaerobic fungi has been suggested as a promising method to increase methane production from lignocellulosic materials [251-254]. Microorganisms that have so far shown positive results on methane yield include the cellulolytic bacteria Clostridium cellulolyticulm, Acetobacteroides hydrogenigenes, and Caldicellulosiruptor lactoaceticus (Caldicellulosiruptor) and the fungus Piromyces rhizinflata. A mix of cultures of different Clostridium sp. and different hemicellulose and cellulolytic bacteria has also been shown to produce positive results [250], while a mixed consortium with high endoglucanase activity has been found to result in increased biogas production from maize silage [255]. For addition of enzymes, investigations have shown mixed effects, ranging from no effect at all on rate or yield, to increased biogas yield only, or increased rate only (summarized in [252]). A likely explanation for the nonconclusive results from addition of enzyme/organisms is differences in the environmental conditions prevailing in the digester, such $\mathrm{pH}$ and ammonia level, which vary greatly depending on substrate. For example, a clear correlation between inefficient cellulose degradation and high-ammonia levels has been demonstrated [53]. The amount of added microorganisms has also been suggested to be of critical importance [250]. For enzyme addition, another possible reason behind the variation in results is that the hydrolytic enzymes investigated so far have mainly originated from nonbiogas environments and have a very short activity lifetime $(<24 \mathrm{~h})$ in the biogas process, which restricts the hydrolytic activity within these systems [256]. However, a study investigating the effects of addition of enzymes or microbes retrieved from a specific biogas environment has found promising results [252]. In that study, these enzymes were found to be active and stable in the environment and had a profound effect on both the biogas production rate and yield from forage ley [252]. Moreover, Azman et al. [257] have demonstrated that addition of hydrolytic enzymes to a cellulose and xylan-fed digester operating at $30^{\circ} \mathrm{C}$ can counteract the inhibitory effects of humic acid on hydrolysis efficiency.

The degradation of fats has been shown to be stimulated by the addition of hydrolyzing enzymes (lipases) or fat-degrading bacteria (Syntrophomonas zehnderi and Clostridium lundense) [250, 258], whereas addition of a co-culture of Syntrophomonas zehnderi and Methanobacterium formicicum is reported to have no effect in AD of fat-rich wastewater [259]. For protein, bioaugmentation with Coprothermobacter proteolyticus has been shown to improve hydrolysis and fermentation in waste-activated sludge [260]. Another factor to consider when attempting to improve the degradation of fat and protein is increased release of LCFA and ammonia. For example, high concentrations of lipases have been shown to inhibit the process, probably due to the release of LCFA. Moreover, LCFA and ammonia have been shown to have additive effects, so that the process becomes more severely inhibited if both are present at relatively high concentrations [205].

Previous attempts to increase the stability and activity of the methanogenic community have included addition of Methanosarcina sp. during start-up [111]. Moreover, bioaugmentation with syntrophic-acetate degrading co-cultures and with ammonia-tolerant Methanoculleus bourgensis has been tested with the aim of preventing ammonia inhibition of the process $[189,261,262]$. Test results in that case revealed that addition of syntrophic co-cultures did not facilitate a dynamic transition from aceticlastic methanogenesis to SAO, whereas addition of ammoniatolerant $M$. bourgensis improved adaptation to gradually increased ammonia concentrations under mesophilic conditions. 


\section{Conclusions}

Biogas production through anaerobic digestion enables recovery of renewable energy and of nutrients from various organic waste materials and is thus highly important for the transition to a more sustainable society. The performance and stability of the biodigestion process is highly dependent on an array of different microbial groups, and their networks and functions are in turn influenced by substrate characteristic and operating parameters. With recent advances in molecular techniques, knowledge about anaerobic microorganisms and their response to various operating conditions has increased tremendously. This knowledge has enabled the development of more controlled management and monitoring approaches, to ensure high process efficiency and stability. However, with increasing knowledge about the microbiology of biogas processes, it has also become evident that the microbiota involved is even more complicated and difficult to visualize than initially thought, particularly as many members within a particular genus are often able to degrade chemically very different compounds. Moreover, many organisms belong to candidate phyla or are even unknown, and remain to be isolated and characterized for full understanding of their role in the biogas system. Thus, in order to establish effective operating policies to achieve maximum biogas process performance, it is important to improve understanding about microorganisms and their functions and to further develop a predictive understanding of the interplay between microbial community structure and operating parameters and performance.

\section{Conflict of interest}

None declared.

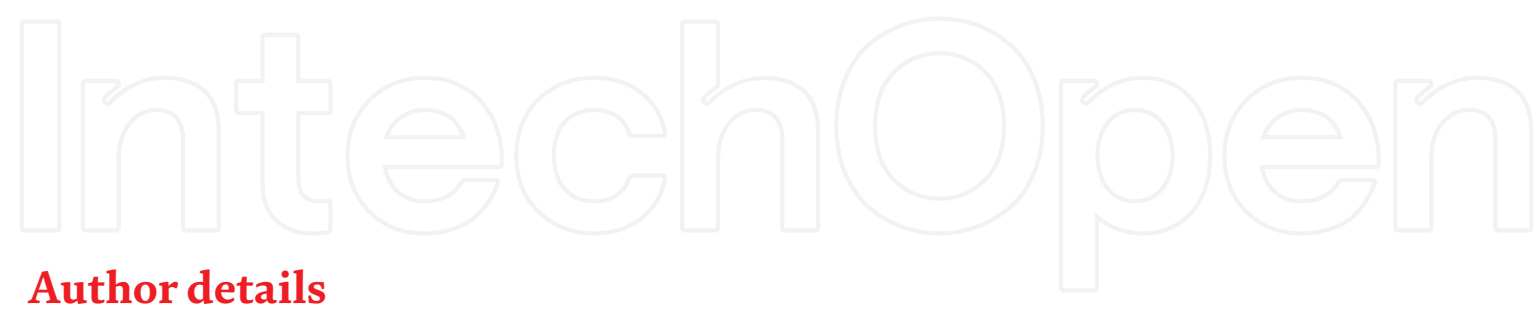

Maria Westerholm and Anna Schnürer*

Department of Molecular Sciences, Swedish University of Agricultural Sciences, Uppsala, Sweden

*Address all correspondence to: anna.schnurer@slu.se

IntechOpen

(C) 2019 The Author(s). Licensee IntechOpen. This chapter is distributed under the terms of the Creative Commons Attribution License (http://creativecommons.org/licenses/ by/3.0), which permits unrestricted use, distribution, and reproduction in any medium, provided the original work is properly cited. (cc) BY 


\section{References}

[1] Weiland P. Biogas production: Current state and perspective. Applied Microbiology and Biotechnology. 2010;85:849-860. DOI: $10.1007 /$ s00253-009-2246-7

[2] Risberg K, Cederlund H, Pell M, Arthurson V, Schnturer A. Comparative characterization of digestate versus pig slurry and cow manure-Chemical composition and effects on soil microbial activity. Waste Management. 2017;61:529538. DOI: 10.1016/j.wasman.2016.12.016

[3] Mata-Alvarez J, Dosta J, RomeroGüiza MS, Fonoll X, Peces M, Astals S. A critical review on anaerobic co-digestion achievements between 2010 and 2013. Renewable and Sustainable Energy Reviews. 2014;36:412-427. DOI: 10.1016/j.rser.2014.04.039

[4] Romero-Gueiza MS, Vila JJ, MataAlvarez J, Chimenos JM, Astals S. The role of additives on anaerobic digestion: A review. Renewable \& Sustainable Energy Reviews. 2016;58:1486-1499. DOI: 10.1016/j.rser.2015.12.094

[5] Westerholm M, Isaksson S, Karlsson Lindsjö O, Schnürer A. Microbial community adaptability to altered temperature conditions determines the potential for process optimisation in biogas production. Applied Energy. 2018;226:838-848. DOI: 10.1016/j. apenergy.2018.06.045

[6] Ferguson RMW, Coulon F, Villa R. Organic loading rate: A promising microbial management tool in anaerobic digestion. Water Research. 2016;100:348-356. DOI: 10.1016/j. watres.2016.05.009

[7] Lindmark J, Thorin E, Fdhila RB, Dahlquist E. Effects of mixing on the result of anaerobic digestion: Review. Renewable and Sustainable Energy Reviews. 2014;40:1030-1047. DOI: 10.1016/j.rser.2014.07.182
[8] Schnürer A, Bohn I, Moestedt J. Protocol for start-up and operation of CSTR biogas processes. In: TJea MG, editor. Hydrocarbon and Lipid Microbiology Protocols. Springer Protocols Handbooks. Berlin Heidelberg: Springer-Verlag; 2017. pp. 171-200

[9] Robles G, Nair RB, Kleinsteuber S, Nikolausz M, Horvath IS. Biogas production: Microbiological aspects.

In: Tabatabaei M, Ghanavati $\mathrm{H}$, editors. Biogas. Biofuel and Biorefinery Technologies. Cham: Springer; 2018. pp. 163-198. DOI: 10.1007/978-3-319-77335-3_7

[10] Kovács E, Wirth R, Mároti G, Bagi Z, Rákhely G, Kovács KL. Biogas production from protein-rich biomass: Fed-batch anaerobic fermentation of casein and of pig blood and associated changes in microbial community composition. PLoS One. 2013;8:1-18. DOI: 10.1371/journal.pone.0077265

[11] He Q, Li L, Zhao X, Qu L, Wu D, Peng $\mathrm{X}$. Investigation of foaming causes in three mesophilic food waste digesters: Reactor performance and microbial analysis. Science Reporter. 2017;7:13701. DOI: $10.1038 / \mathrm{s} 41598-017-14258-3$

[12] Lienen T, Kleyboecker A, Verstraete W, Wuerdemann H. Foam formation in a downstream digester of a cascade running full-scale biogas plant: Influence of fat, oil and grease addition and abundance of the filamentous bacterium Microthrix parvicella. Bioresource Technology. 2014;153:1-7. DOI: 10.1016/j.biortech.2013.11.017

[13] Sánchez ÒJ, Cardona CA. Trends in biotechnological production of fuel ethanol from different feedstocks. Bioresource Technology. 2008;99:52705295. DOI: 10.1016/j.biortech.2007.11.013

[14] Azman S, Khadem AF, van Lier JB, Zeeman G, Plugge CM. Presence and 
role of anaerobic hydrolytic microbes in conversion of lignocellulosic biomass for biogas production. Critical Reviews in Environmental Science and Technology. 2015;45:2523-2564. DOI: $10.1080 / 10643389.2015 .1053727$

[15] Lynd LR, Weimer PJ, van Zyl WH, Pretorius IS. Microbial cellulose utilization: Fundamentals and biotechnology. Microbiology and Molecular Biology Reviews. 2002;66:506-577. DOI: $10.1128 /$ MMBR.66.3.506-577.2002

[16] Wagner AO, Lackner N, Mutschlechner M, Prem EM, Markt R, Illmer P. Biological pretreatment strategies for second-generation lignocellulosic resources to enhance biogas production. Energies. 2018;11:1797. DOI: 10.3390/ en11071797

[17] Moestedt J, Nilsson Påledal S, Schnürer A, Nordell E. Biogas production from thin stillage on an industrial scale-Experience and optimisation. Energies. 2013;6: 5642-5655. DOI: 10.3390/en6115642

[18] Solli L, Elise Håvelsrud O, Horn SJ, Gunn Rike A. A metagenomic study of the microbial communities in four parallel biogas reactors. Biotechnology for Biofuels. 2014;7:1-15. DOI: 10.1186/ s13068-014-0146-2

[19] Rajagopal R, Massé DI, Singh G. A critical review on inhibition of anaerobic digestion process by excess ammonia. Bioresource Technology. 2013;143:632-641. DOI: 10.1016/j. biortech.2013.06.030

[20] Luo G, Fotidis IA, Angelidaki I. Comparative analysis of taxonomic, functional, and metabolic patterns of microbiomes from 14 full-scale biogas reactors by metagenomic sequencing and radioisotopic analysis. Biotechnology for Biofuels. 2016;9:1-12. DOI: 10.1186/s13068-016-0465-6
[21] Banks CJ, Zhang Y, Jiang Y, Heaven $S$. Trace elements requirements for stable food waste digestion at elevated ammonia concentrations. Bioresource Technology. 2012;104:127-135. DOI: 10.1016/j.biortech.2011.10.068

[22] Angelidaki I, Karakashev D, Batstone DJ, Plugge CM, Stams AJM. Biomethane and its potential. Methods in Enzymology. 2011;494:327-351. DOI: 10.1016/B978-0-12-385112-3.00016-0

[23] Sousa DZ, Smidt H, Alves MM, Stams AJM. Ecophysiology of syntrophic communities that degrade saturated and unsaturated long-chain fatty acids. FEMS Microbiology Ecology. 2009;68:257-272. DOI: 10.1111/j.1574-6941.2009.00680.x

[24] Luostarinen S, Luste S, Sillanpää $M$. Increased biogas production at wastewater treatment plants through co-digestion of sewage sludge with grease trap sludge from a meat processing plant. Bioresource Technology. 2009;100:79-85. DOI: 10.1016/j.biortech.2008.06.029

[25] Affes M, Aloui F, Hadrich F, Loukil S, Sayadi S. Effect of bacterial lipase on anaerobic co-digestion of slaughterhouse wastewater and grease in batch condition and continuous fixed-bed reactor. Lipids in Health and Disease. 2017;16:195. DOI: 10.1186/s12944-017-0587-2

[26] Hanaki K. Mechanism of inhibition caused by long-chain fatty acids in anaerobic digestion process. Biotechnology and Bioengineering. 1981;23:1591-1610

[27] Cuetos MJ, Gómez X, Otero M, Morán A. Anaerobic digestion of solid slaughterhouse waste (SHW) at laboratory scale: Influence of co-digestion with the organic fraction of municipal solid waste (OFMSW). Biochemical Engineering Journal. 2008;40:99-106. DOI: 10.1016/j. bej.2007.11.019 
[28] Cirne DG, Lehtomäki A, Björnsson L, Blackall LL. Hydrolysis and microbial community analyses in two-stage anaerobic digestion of energy crops. Journal of Applied Microbiology. 2007;103:516-527. DOI: 10.1111/j.1365-2672.2006.03270.x

[29] Kazda M, Langer S, Bengelsdorf FR. Fungi open new possibilities for anaerobic fermentation of organic residues. Energy, Sustainability and Society. 2014;4:6. DOI: 10.1186/2192-0567-4-6

[30] Schnürer A. Biogas production: Microbiology and technology. Advances in Biochemical Engineering/ Biotechnology. In: Hatti-Kaul R, Mamo G, Mattiasson B, editors. Switzerland: Springer International Publishing; 2016;156:195-234. DOI: 10.1007/10_2016_5

[31] Tsavkelova EA, Netrusov AI. Biogas production from cellulose containing substrates: A review. Applied Biochemistry and Microbiology. 2012;48:421-433. DOI: 10.1134/ S0003683812050134

[32] Ding S, Liu Y, Zeng Y, Himmel ME, Baker JO, Bayer EA. How does plant cell wall nanoscale architecture correlate with enzymatic digestibility? Science. 2012;338:1055-1060. DOI: 10.1126/ science.1227491

[33] Ramsay IR, Pullammanappallil PC. Protein degradation during anaerobic wastewater treatment: Derivation of stoichiometry. Biodegradation. 2001;12:247-257. DOI: 10.1023/A:1013116728817

[34] Schink B, Stams AJM. Syntrophism among prokaryotes. In: Dworkin M, Falkow S, Rosenberg E, Schleifer KH, Stackebrandt E, editors. The Prokaryotes. New York: Springer-Verlag; 2006. pp. 309-335

[35] Mendes AA, Oliveira PC, de Castro HF. Properties and biotechnological applications of porcine pancreatic lipase. Journal of Molecular Catalysis B: Enzymatic. 2012;78:119-134. DOI: 10.1016/j.molcatb.2012.03.004

[36] Stergiou P, Foukis A, Filippou M, Koukouritaki M, Parapouli M, Theodorou LG, et al. Advances in lipase-catalyzed esterification reactions. Biotechnology Advances. 2013;31:1846-1859. DOI: 10.1016/j. biotechadv.2013.08.006

[37] Weng C, Jeris JS. Biochemical mechanisms in the methane fermentation of glutamic and oleic acids. Water Research. 1974;10:9-18

[38] Ma J, Zhao Q-B, Laurens LLM, Jarvis EE, Nagle NJ, Chen S, et al. Mechanism, kinetics and microbiology of inhibition caused by long-chain fatty acids in anaerobic digestion of algal biomass. Biotechnology for Biofuels. 2015;8:141. DOI: 10.1186/s13068-015-0322-z

[39] Kougias PG, Angelidaki I. Biogas and its opportunities-A review. Frontiers of Environmental Science \& Engineering. 2018;12:14. DOI: $10.1007 /$ s11783-018-1037-8

[40] Kandylis P, Bekatorou A, Pissaridi K, Lappa K, Dima A, Kanellaki M, et al. Acidogenesis of cellulosic hydrolysates for new generation biofuels. Biomass and Bioenergy. 2016;91:210-216. DOI: 10.1016/j.biombioe.2016.05.006

[41] Ragsdale S, Pierce E. Acetogenesis and the Wood-Ljungdahl pathway of $\mathrm{CO}_{2}$ fixation. Biochimica et Biophysica Acta. 2008;1784:1873-1898. DOI: 10.1016/j.bbapap.2008.08.012

[42] Drake HL, Gossner AS, Daniel SL. Old acetogens, new light. Annals of the New York Academy of Sciences. 2008;1125:100-128. DOI: 10.1196/ annals.1419.016

[43] Worm P, Müller N, Plugge CM, Stams AJM, Schink B. Syntrophy 
in methanogenic degradation. In: Hackstein JHP, editor. (Endo)symbiotic Methanogenic Archaea. Berlin: Springer-Verlag; 2010. pp. 143-173

[44] Schink B. Energetics of syntrophic cooperation in methanogenic degradation. Microbiology and Molecular Biology Reviews. 1997;61:262-280

[45] Dong X, Plugge CM, Stams AJM. Anaerobic degradation of propionate by a mesophilic acetogenic bacterium in coculture and triculture with different methanogens. Applied and Environmental Microbiology. 1994;60:2834-2838

[46] Liu F, Whitman WB. Metabolic, phylogenetic, and ecological diversity of the methanogenic archaea. Annals of the New York Academy of Sciences. 2008;1125:171-189. DOI: 10.1196/ annals.1419.019

[47] Costa KC, Leigh JA. Metabolic versatility in methanogens. Current Opinion in Biotechnology. 2014;29:70-75. DOI: 10.1016/j.copbio.2014.02.012

[48] Lebuhn M, Hanreich A, Klocke M, Schlüter A, Bauer C, Pérez CM. Towards molecular biomarkers for biogas production from lignocellulose-rich substrates. Anaerobe. 2014;29:10-21. DOI: 10.1016/j.anaerobe.2014.04.006

[49] Krause L, Diaz NN, Edwards RA, Gartemann K, Krömeke H, Neuweger H, et al. Taxonomic composition and gene content of a methane-producing microbial community isolated from a biogas reactor. Journal of Biotechnology. 2008;136:91101. DOI: 10.1016/j.jbiotec.2008.06.003

[50] Klocke M, Mähnert P, Mundt K, Souidi K, Linke B. Microbial community analysis of a biogas-producing completely stirred tank reactor fed continuously with fodder beet silage as mono-substrate. Systematic and Applied Microbiology. 2007;30:139-151. DOI: 10.1016/j.syapm.2006.03.007
[51] Wang H, Lehtomäki A, Tolvanen K, Puhakka J, Rintala J. Impact of crop species on bacterial community structure during anaerobic co-digestion of crops and cow manure. Bioresource Technology. 2009;100:2311-2315. DOI: 10.1016/j.biortech.2008.10.040

[52] Liu T, Sun L, Müller B, Schnürer A. Importance of inoculum source and initial community structure for biogas production from agricultural substrates. Bioresource Technology. 2017;245:768-

777. DOI: 10.1016/j.biortech.2017.08.213

[53] Sun L, Liu T, Müller B, Schnürer A. The microbial community structure in industrial biogas plants influences the degradation rate of straw and cellulose in batch tests. Biotechnology for Biofuels. 2016;9:128. DOI: 10.1186/ s13068-016-0543-9

[54] Jia Y, Ng S, Lu H, Cai M, Lee PKH. Genome-centric metatranscriptomes and ecological roles of the active microbial populations during cellulosic biomass anaerobic digestion. Biotechnology for

Biofuels. 2018;11:117. DOI: 10.1186/ s13068-018-1121-0

[55] Campanaro S, Treu L, Kougias PG, Francisci DD, Valle G, Angelidaki I. Metagenomic analysis and functional characterization of the biogas microbiome using high throughput shotgun sequencing and a novel binning strategy. Biotechnology for Biofuels. 2016;9:26. DOI: 10.1186/s13068-016-0441-1

[56] Koeck DE, Wibberg D, Maus I, Winkler A, Albersmeier A, Zverlov VV, et al. Complete genome sequence of the cellulolytic thermophile Ruminoclostridium cellulosi wild-type strain DG5 isolated from a thermophilic biogas plant. Journal of Biotechnology. 2014;188:136-137. DOI: 10.1016/j.jbiotec.2014.08.024

[57] Liu CM, Wachemo AC, Tong H, Shi SH, Zhang L, Yuan HR, et al. Biogas production and microbial community 
properties during anaerobic digestion of corn stover at different temperatures. Bioresource Technology. 2018;261:93103. DOI: 10.1016/j.biortech.2017.12.076

[58] Limam RD, Chouari R, Mazéas L, Wu T, Li T, Grossin-Debattista J, et al. Members of the uncultured bacterial candidate division WWE1 are implicated in anaerobic digestion of cellulose. Microbiology Open. 2014;3:157-167. DOI: 10.1002/mbo3.144

[59] Wang C, Dong D, Wang H, Mueller $\mathrm{K}$, Qin $\mathrm{Y}$, Wang $\mathrm{H}$, et al. Metagenomic analysis of microbial consortia enriched from compost: New insights into the role of Actinobacteria in lignocellulose decomposition. Biotechnology for Biofuels. 2016;9:22. DOI: 10.1186/ s13068-016-0440-2

[60] Dollhofer V, Podmirseg SM, Callaghan TM, Griffith GW, Fliegerova $\mathrm{K}$. Anaerobic fungi and their potential for biogas production. In: Guebitz $G$, Bauer A, Bochmann G, Gronauer A, Weiss S, editors. Biogas Science and Technology. Advances in Biochemical Engineering/Biotechnology. Vol. 151. Cham: Springer; 2015. DOI: 10.1007/978-3-319-21993-6_2

[61] Cheng YF, Shi QC, Sun RL, Liang D, Li YF, Li YQ, et al. The biotechnological potential of anaerobic fungi on fiber degradation and methane production. World Journal of Microbiology and Biotechnology. 2018;34:155. DOI: 10.1007/s11274-018-2539-z

[62] Baena S, Fardeau ML, Ollivier B, Labat M, Thomas P, Garcia JL, et al. Aminomonas paucivorans gen. nov., sp. nov., a mesophilic, anaerobic, amino acid-utilizing bacterium. International Journal of Systematic Bacteriology. 1999;49:975-982. DOI: 10.1099/00207713-49-3-975

[63] Baena S, Fardeau M, Woo THS, Ollivier B, Labat M, Patel BKC. Phylogenetic relationships of three amino-acid-utilizing anaerobes, Selenomonas acidaminovorans, 'Selenomonas acidaminophila' and Eubacterium acidaminophilum, as inferred from partial 16S rDNA nucleotide sequences and proposal of Thermanaerovibrio acidaminovorans gen. nov., comb. nov. and Anaeromusa acidaminophila gen. nov., comb. nov. International Journal of Systematic Bacteriology. 1999;49:969-974

[64] Baena S, Fardeau ML, Labat M, Ollivier B, Garcia JL, Patel BKC. Aminobacterium mobile sp. nov., a new anaerobic amino acid-degrading bacterium. International Journal of Systematic and Evolutionary Microbiology. 2000;50:259-264

[65] Ueki A, Abe K, Suzuki D, Kaku N, Watanabe K, Ueki K. Anaerosphaera aminiphila gen. nov., sp nov., a glutamatedegrading, Gram-positive anaerobic coccus isolated from a methanogenic reactor treating cattle waste. International Journal of Systematic and Evolutionary Microbiology. 2009;59:3161-3167. DOI: 10.1099/ijs.0.011858-0

[66] Plugge CM, Balk M, Zoetendal EG, Stams AJM. Gelria glutamica gen. nov., sp nov., a thermophilic, obligately syntrophic, glutamate-degrading anaerobe. International Journal of Systematic and Evolutionary Microbiology. 2002;52:401-407. DOI: 10.1099/ijs.0.01949-0

[67] Tomazetto G, Hahnke S, Maus I, Wibberg D, Puehler A, Schlueter A, et al. Complete genome sequence of Peptoniphilus sp strain ING2-D1G isolated from a mesophilic lab-scale completely stirred tank reactor utilizing maize silage in co-digestion with pig and cattle manure for biomethanation. Journal of Biotechnology. 2014;192:5961. DOI: 10.1016/j.jbiotec.2014.09.011

[68] Tang Y, Shigematsu T, Morimura S, Kida K. Microbial community analysis of mesophilic anaerobic protein degradation 
process using bovine serum albumin (BSA)-fed continuous cultivation. Journal of Bioscience and Bioengineering. 2005;99:150-164. DOI: 10.1263/jbb.99.150

[69] Hahnke S, Langer T, Klocke M. Proteiniborus indolifex sp nov., isolated from a thermophilic industrial-scale biogas plant. International Journal of Systematic and Evolutionary Microbiology. 2018;68:824-828. DOI: 10.1099/ijsem.0.002591

[70] Hernandez-Eugenio G, Fardeau ML, Cayol JL, Patel BK, Thomas P, Macarie H, et al. Sporanaerobacter acetigenes gen. nov., sp. nov., a novel acetogenic, facultatively sulfurreducing bacterium. International Journal of Systematic and Evolutionary Microbiology. 2002;52:1217-1223. DOI: 10.1099/00207713-52-4-1217

[71] Hahnke S, Langer T, Koeck DE, Klocke M. Description of Proteiniphilum saccharofermentans sp. nov., Petrimonas mucosa sp. nov. and Fermentimonas caenicola gen. nov., sp. nov., isolated from mesophilic laboratory-scale biogas reactors, and emended description of the genus Proteiniphilum. International Journal of Systematic and Evolutionary Microbiology. 2016;66:1466-1475. DOI: 10.1099/ijsem.0.000902

[72] Stolze Y, Bremges A, Maus I, Pühler A, Sczyrba A, Schlüter A. Targeted in situ metatranscriptomics for selected taxa from mesophilic and thermophilic biogas plants. Microbial Biotechnology. 2017;11:667-679. DOI: 10.1111/1751-7915.12982

[73] Li A, Chu Y, Wang X, Ren L, Yu J, Liu X, et al. A pyrosequencing-based metagenomic study of methaneproducing microbial community in solid-state biogas reactor. Biotechnology for Biofuels. 2013;6:3. DOI:

10.1186/1754-6834-6-3

[74] Petropoulos E, Dolfing J, Yu Y, Wade MJ, Bowen EJ, Davenporta RJ, Curtis
TP. Lipolysis of domestic wastewater in anaerobic reactors operating at low temperatures. Environmental Science: Water Research \& Technology. 2018;4:1002. DOI: 10.1039/c8ew00156a

[75] St-Pierre B, Wright A-DG. Comparative metagenomic analysis of bacterial populations in three fullscale mesophilic anaerobic manure digesters. Applied Microbiology and Biotechnology. 2014;98:2709-2717. DOI: 10.1007/s00253-013-5220-3

[76] Ziels RM, Sousa DZ, Stensel HD, Beck DAC. DNA-SIP based genomecentric metagenomics identifies key long-chain fatty acid-degrading populations in anaerobic digesters with different feeding frequencies. The ISME Journal. 2018;12:112-123. DOI: 10.1038/ ismej.2017.143

[77] Worm P, Koehorst JJ, Visser M, Sedano-Núnez VT, Schaap PJ, Plugge CM, et al. A genomic view on syntrophic versus non-syntrophic lifestyle in anaerobic acid degrading communities. Biochimica et Biophysica Acta. 2014;1837:2004-2016. DOI: 10.1016/j.bbabio.2014.06.005

[78] Nobu MK, Narihiro T, Rinke C, Kamagata Y, Tringe SG, Woyke T, et al. Microbial dark matter ecogenomics reveals complex synergistic network in a methanogenic bioreactor. The ISME Journal. 2015;9:1710-1722. DOI: 10.1038/ ismej.2014.256

[79] Pelletier E, Kreimeyer A, Bocs S, Rouy Z, Gyapay G, Chouari R, et al. "Candidatus Cloacamonas Acidaminovorans": Genome sequence reconstruction provides a first glimpse of a new bacterial division. Journal of Bacteriology. 2008;190:2572-2579. DOI: 10.1128/JB.01248-07

[80] Li J, Rui J, Yao M, Zhang S, Yan X, Wang Y, et al. Substrate type and free ammonia determine bacterial community structure in full-scale 
mesophilic anaerobic digesters treating cattle or swine manure. Frontiers in Microbiology. 2015;6:1337. DOI: 10.3389/fmicb.2015.01337

[81] Westerholm M, Moestedt J, Schnürer A. Biogas production through syntrophic acetate oxidation and deliberate operating strategies for improved digester performance. Applied Energy. 2016;179:124-135. DOI: 10.1016/j.apenergy.2016.06.061

[82] Müller B, Sun L, Westerholm M, Schnürer A. Bacterial community composition and fhs profiles of lowand high-ammonia biogas digesters reveal novel syntrophic acetateoxidising bacteria. Biotechnology for Biofuels. 2016;9:1-18. DOI: 10.1186/ s13068-016-0454-9

[83] Zakrzewski M, Goesmann A, Jaenicke S, Jünemann S, Eikmeyer F, Szczepanowski R, et al. Profiling of the metabolically active community from a production-scale biogas plant by means of high-throughput metatranscriptome sequencing. Journal of Biotechnology. 2012;158:248-258. DOI: 10.1016/j. jbiotec.2012.01.020

[84] Westerholm M, Müller B, Singh A, Karlsson Lindsjö O, Schnürer A. Detection of novel syntrophic acetate-oxidising bacteria from biogas processes by continuous acetate enrichment approaches. Microbial Biotechnology. 2018;11:680-693. DOI: 10.1111/1751-7915.13035

[85] Mosbaek FHK, Mulat DG, Albertsen M, Ward AJ, Feilberg A, et al. Identification of syntrophic acetateoxidizing bacteria in anaerobic digesters by combined protein-based stable isotope probing and metagenomics. The ISME Journal. 2016:1-14. DOI: 10.1038/ ismej.2016.39

[86] Bassani I, Kougias PG, Treu L, Angelidaki I. Biogas upgrading via hydrogenotrophic methanogenesis in two-stage continuous stirred tank reactors at mesophilic and thermophilic conditions. Environmental Science \& Technology. 2015;49:12585-12593. DOI: 10.1021/acs.est.5b03451

[87] Ito T, Yoshiguchi K, Ariesyady HD, Okabe S. Identification of a novel acetate-utilizing bacterium belonging to Synergistes group 4 in anaerobic digester sludge. The ISME Journal. 2011;5: 1844-1856. DOI: 10.1038/ismej.2011.59

[88] Ho D, Jensen P, Batstone D. Effects of temperature and hydraulic retention time on acetotrophic pathways and performance in high-rate sludge digestion. Environmental Science \& Technology. 2014;48:6468-6476. DOI: 10.1021/es500074j

[89] Lee S, Park J, Kim SH, Yu BJ, Yoon J, Park H. Evidence off syntrophic acetate oxidation by Spirochaetes during anaerobic methane production. Bioresource Technology. 2015;190:543-549. DOI: 10.1016/j. biortech.2015.02.066

[90] Ruiz-Sánchez J, Campanaro S, Guivernau M, Fernández B, PrenafetaBoldú FX. Effect of ammonia on the active microbiome and metagenome from stable full-scale digesters. Bioresource Technology. 2018;250:513-522. DOI: 10.1016/j.biortech.2017.11.068

[91] Maus I, Koeck DE, Cibis KG, Hahnke S, Kim YS, Langer T, et al. Unraveling the microbiome of a thermophilic biogas plant by metagenome and metatranscriptome analysis complemented by characterization of bacterial and archaeal isolates. Biotechnology for Biofuels. 2016;9:171. DOI: 10.1186/s13068-016-0581-3

[92] Heyer R, Kohrs F, Benndorf D, Rapp E, Kausmann R, Heiermann M, et al. Metaproteome analysis of the microbial communities in agricultural biogas plants. New Biotechnology. 
2013;30:614-622. DOI: $10.1016 / j$. nbt.2013.01.002

[93] Enzmann F, Mayer F, Rother M, Holtmann D. Methanogens: Biochemical background and biotechnological applications. AMB Express. 2018;8:1. DOI: $10.1186 / \mathrm{s} 13568-017-0531-\mathrm{x}$

[94] De Vrieze J, Hennebel T, Boon N, Verstraete W. Methanosarcina: The rediscovered methanogen for heavy duty biomethanation. Bioresource Technology. 2012;112:1-9. DOI: 10.1016/j.biortech.2012.02.079

[95] Nubo KM, Narihiro T, Kuroda K, Mei R, Liu WT. Chasing the elusive Euryarchaeota class WSA2: Genomes reveal a uniquely fastidious methylreducing methanogen. The ISME Journal. 2016;10:2478-2487. DOI: $1751-7362 / 16$

[96] Lebuhn M, Weiss S, Munk B, Guebitz GM. Microbiology and molecular biology tools for biogas process analysis, diagnosis and control. 2015. p. 1-40.

[97] De Vrieze J, Pinto AJ, Sloan WT, Ijaz UZ. The active microbial community more accurately reflects the anaerobic digestion process: $16 \mathrm{~S}$ rRNA (gene) sequencing as a predictive tool. Microbiome. 2018;6:63. DOI: 10.1186/ s40168-018-0449-9

[98] Hassa J, Maus I, Off S, Puehler A, Scherer P, Klocke M, et al. Metagenome, metatranscriptome, and metaproteome approaches unraveled compositions and functional relationships of microbial communities residing in biogas plants. Applied Microbiology and Biotechnology. 2018;102:5045-5063. DOI: $10.1007 / \mathrm{s} 00253-018-8976-7$

[99] Maus I, Rumming M, Bergmann I, Heeg K, Pohl M, Nettmann E, et al. Characterization of Bathyarchaeota genomes assembled from metagenomes of biofilms residing in mesophilic and thermophilic biogas reactors. Biotechnology for Biofuels. 2018;11:167. DOI: 10.1186/s13068-018-1162-4

[100] De Vrieze J, Gildemyn S, VilchezVargas R, Jáuregui R, Pieper DH, Verstraete $\mathrm{W}$, et al. Inoculum selection is crucial to ensure operational stability in anaerobic digestion. Applied Microbiology and Biotechnology. 2015;99:189-199. DOI: $10.1007 /$ s00253-014-6046-3

[101] Raposo F, Fernandez-Cegri V, De la Rubia MA, Borja R, Beline F, Cavinato C, et al. Biochemical methane potential (BMP) of solid organic substrates: Evaluation of anaerobic biodegradability using data from an international interlaboratory study. Journal of Chemical Technology and Biotechnology. 2011;86:1088-1098. DOI: 10.1002/jctb.2622

[102] Han S, Liu YF, Zhang SC, Luo G. Reactor performances and microbial communities of biogas reactors: Effects of inoculum sources. Applied Microbiology and Biotechnology. 2016;100:987-995. DOI: 10.1007/ s00253-015-7062-7

[103] Wojcieszak M, Pyzik A, Poszytek K, Krawczyk PS, Sobczak A, Lipinski L, et al. Adaptation of methanogenic inocula to anaerobic digestion of maize silage. Frontiers in Microbiology. 2017;8:1881. DOI: $10.3389 /$ fmicb.2017.01881

[104] Satpathy P, Steinigeweg S, Cypionka H, Engelen B. Different substrates and starter inocula govern microbial community structures in biogas reactors. Environmental Technology. 2016;37:1441-1450. DOI: 10.1080/09593330.2015.1118559

[105] Parra-Orobio BA, Donoso-Bravo A, Ruiz-Sanchez JC, Valencia-Molina KJ, Torres-Lozada P. Effect of inoculum on the anaerobic digestion of food waste accounting for the concentration of trace elements. Waste Management. 
2018;71:342-349. DOI: 10.1016/j. wasman.2017.09.040

[106] De Vrieze J, Saunders AM, He Y, Fang J, Nielsen PH, Verstraete W, et al. Ammonia and temperature determine potential clustering in the anaerobic digestion microbiome. Water Research. 2015;75:312-323. DOI: 10.1016/j. watres.2015.02.025

[107] Sundberg C, Al-Soud WA, Larsson M, Alm EJ, Yekta SS, Svensson BH, et al. 454 pyrosequencing analyses of bacterial and archaeal richness in 21 full-scale biogas digesters. FEMS Microbiology Ecology. 2013;85:612-626. DOI: 10.1111/1574-6941.12148

[108] Koch K, Lippert T, Drewes JE. The role of inoculum's origin on the methane yield of different substrates in biochemical methane potential (BMP) tests. Bioresource Technology. 2017;243:457-463. DOI: 10.1016/j. biortech.2017.06.142

[109] Moreno-Andrade I, Buitron G. Influence of the origin of the inoculum on the anaerobic biodegradability test. Water Science and Technology. 2004;49:53-59. DOI: 10.2166/wst.2004.0017

[110] Rosenfeld JS. Functional redundancy in ecology and conservation. Oikos. 2002;98:156-162. DOI: 10.1034/j.1600-0706.2002.980116.x

[111] Lins P, Reitschuler C, Illmer P. Methanosarcina spp., the key to relieve the start-up of a thermophilic anaerobic digestion suffering from high acetic acid loads. Bioresource Technology. 2014;152:347-354. DOI: 10.1016/j. biortech.2013.11.020

[112] Liu T, Sun L, Nordberg A, Schnurer A. Substrate-induced response in biogas process performance and microbial community relates back to inoculum source. Microorganisms. 2018;6:E80. DOI: 10.3390/ microorganisms 6030080
[113] Hagen LH, Vivekanand V, Linjordet R, Pope PB, Eijsink VGH, Horn SJ. Microbial community structure and dynamics during co-digestion of whey permeate and cow manure in continuous stirred tank reactor systems. Bioresource Technology. 2014;171:350-359. DOI: 10.1016/j.biortech.2014.08.095

[114] Levén L, Eriksson A, Schnürer A. Effect of process temperature on bacterial and archaeal communities in two methanogenic bioreactors treating organic household waste. FEMS Microbiology Ecology. 2007;59:683-693. DOI: 10.1111/j.1574-6941.2006.00263.x

[115] Labatut RA, Angenent LT, Scott NR. Conventional mesophilic vs. thermophilic anaerobic digestion: A tradeoff between performance and stability? Water Research. 2014;53:249-258. DOI: 10.1016/j.watres.2014.01.035

[116] Pap B, Györkei Á, Boboescu IZ, Nagy IK, Bíró T, Kondorosi É, et al. Temperature-dependent transformation of biogas-producing microbial communities points to the increased importance of hydrogentrophic methanogenesis under thermophilic operation. Bioresource Technology. 2015;177: 375-380. DOI: 10.1016/j. biortech.2014.11.021

[117] Mei R, Nobu MK, Narihiro T, Kuroda K, Sierra JM, Wu Z, et al. Operation-driven heterogeneity and overlooked feed-associated populations in global anaerobic digester microbiome. Water Research. 2017;124:77-84. DOI: 10.1016/j. watres.2017.07.050

[118] Sun L, Pope PB, Eijsink VGH, Schnürer A. Characterization of microbial community structure during continuous anaerobic digestion of straw and cow manure. Microbial Biotechnology. 2015;8:815-827. DOI: 10.1111/1751-7915.12298 
[119] Moestedt J, Nordell E, Schnürer A. Comparison of operational strategies for increased biogas production from thin stillage. Journal of Biotechnology. 2014;175:22-30. DOI: 10.1016/j. jbiotec.2014.01.030

[120] Westerholm M, Müller B, Isaksson S, Schnürer A. Trace element and temperature effects on microbial communities and links to biogas digester performance at high ammonia levels. Biotechnology for Biofuels. 2015;8:1-19. DOI: 10.1186/ s13068-015-0328-6

[121] Hupfauf S, Plattner P, Wagner AO, Kaufmann R, Insam H, Podmirseg SM. Temperature shapes the microbiota in anaerobic digestion and drives efficiency to a maximum at $45^{\circ} \mathrm{C}$. Bioresource Technology. 2018;269: 309-318. DOI: 10.1016/j.

biortech.2018.08.106

[122] Dhaked RK, Singh P, Singh L. Biomethanation under psychrophilic conditions. Waste Management. 2010;30:2490-2496. DOI: 10.1016/j. wasman.2010.07.015

[123] Lin Q, De Vrieze J, He G, Li X, Li J. Temperature regulates methane production through the function centralization of microbial community in anaerobic digestion. Bioresource Technology. 2016;216:150-158. DOI: 10.1016/j.biortech.2016.05.046

[124] Chen H, Chang S. Impact of temperatures on microbial community structures of sewage sludge biological hydrolysis. Bioresource Technology. 2017;245:502-510. DOI: 10.1016/j.biortech.2017.08.143

[125] Hwu C, Lettinga G. Acute toxicity of oleate to acetate-utilizing methanogens in mesophilic and thermophilic anaerobic sludges. Enzyme and Microbial Technology. 1997;21:297-301. DOI: 10.1016/ S0141-0229(97)00050-1
[126] Levén L, Nyberg K, Schnürer A. Conversion of phenols during anaerobic digestion of organic solid waste-A review of important microorganisms and impact of temperature. Journal of Environmental Management. 2011;95:99-103. DOI: 10.1016/j. jenvman.2010.10.021

[127] Lindorfer H, Waltenberg R, Köller K, Braun R, Kirchmayr R. New data on temperature optimum and temperature changes in energy crop digesters. Bioresource Technology. 2008;99:7011-7019

[128] Moestedt J, Nordell E, Schnürer A. Comparison of operating strategies for increased biogas production from thin stillage. Journal of Biotechnology. 2014;175:22-30. DOI: 10.1016/j.

jbiotec.2014.01.030

[129] Risberg K, Sun L, Levén L, Horn SJ, Schnürer A. Biogas production from wheat straw and manure-Impact of pretreatment and process operating parameters. Bioresource Technology. 2013;149:232-237

[130] Ziembinska-Buczynska A, Banach A, Bacza T, Pieczykolan M. Diversity and variability of methanogens during the shift from mesophilic to thermohilic conditions while biogas production. World Journal of Microbiology and Biotechnology. 2014;30:3047-3053

[131] Drosg B. Process Monitoring in Biogas Plants. IEA Bioenergy; 2013.

Technical Brochure

[132] Kim MS, Kim DH, Yun YM. Effect of operation temperature on anaerobic digestion of food waste: Performance and microbial analysis. Fuel. 2017;209:598-605. DOI: 10.1016/j. fuel.2017.08.033

[133] Chapleur O, Mazeas L, Godon J, Bouchez T. Asymmetrical response of anaerobic digestion microbiota 
to temperature changes. Applied Microbiology and Biotechnology. 2016;100:1445-1457. DOI: 10.1007/ s00253-015-7046-7

[134] Moset V, Poulsen M, Wahid R, Hojberg O, Moller HB. Mesophilic versus thermophilic anaerobic digestion of cattle manure: methane productivity and microbial ecology. Microbial Biotechnology. 2015;8:787-800

[135] Jang HM, Ha JH, Kim M, Kim J, Kim YM, Park JM. Effect of increased load of high-strength food wastewater in thermophilic and mesophilic anaerobic co-digestion of waste activated sludge on bacterial community structure. Water Research. 2016;99:140-148. DOI: 10.1016/j.watres.2016.04.051

[136] Theuerl S, Klang J, Heiermann M, De Vrieze J. Marker microbiome clusters are determined by operational parameters and specific key taxa combinations in anaerobic digestion. Bioresource Technology. 2018;263:128-135. DOI: 10.1016/j.biortech.2018.04.111

[137] Ahlberg-Eliasson K, Liu T, Nadeau E, Schnurer A. Forage types and origin of manure in codigestion affect methane yield and microbial community structure. Grass and Forage Science. 2018;73:740-757. DOI: 10.1111/ gfs.12358

[138] Chen S, Cheng H, Wyckoff KN, He Q. Linkages of Firmicutes and Bacteroidetes populations to methanogenic process performance. Journal of Industrial Microbiology \& Biotechnology. 2016;43:771-781. DOI: 10.1007/s10295-016-1760-8

[139] Güllert S, Fischer MA, Turaev D, Noebauer B, Ilmberger N, Wemheuer B, et al. Deep metagenome and metatranscriptome analyses of microbial communities affiliated with an industrial biogas fermenter, a cow rumen, and elephant feces reveal major differences in carbohydrate hydrolysis strategies.
Biotechnology for Biofuels. 2016;9:121.

DOI: 10.1186/s13068-016-0534-x

[140] Stolze Y, Bremges A, Rumming M, Henke C, Maus I, Pühler A, et al. Identification and genome reconstruction of aundant distinct taxa in microbiomes from one thermophilic and three mesophilic productionscale biogas plants. Biotechnology for Biofuels. 2016;9:156. DOI: 10.1186/ s13068-016-0565-3

[141] Zamanzadeh M, Hagen LH, Svensson K, Linjordet R, Horn SJ. Anaerobic digestion of food wasteEffect of recirculation and temperature on performance and microbiology. Water Research. 2016;96:246-254. DOI: 10.1016/j.watres.2016.03.058

[142] Guo X, Wang C, Sun F, Shu W, Wu W. A comparison of microbial characteristics between the thermophilic and mesophilic anaerobic digesters exposed to elevated food waste loadings. Bioresource Technology. 2014;152:420-428. DOI: 10.1016/j. biortech.2013.11.012

[143] Tian Z, Zhang Y, Li YF, Chi Y, Yang M. Rapid establishment of thermophilic anaerobic microbial community during the one-step startup of thermophilic anaerobic digestion from a mesophilic digester. Water Research. 2015;69:9-19. DOI: 10.1016/j.watres.2014.11.001

[144] Maus I, Cibis KG, Bremges A, Stolze Y, Wibberg D, Blom J, et al. Genomic characterization of Defluviitoga tunisiensis L3, a key hydrolytic bacterium in a thermophilic biogas plant. Journal of Biotechnology. 2016;232:50-60. DOI: 10.1016/j. jbiotec.2016.05.001

[145] Balk M, Weijma J, Stams AJM. Thermotoga lettingae sp. nov., a novel thermophilic, methanol-degrading bacterium isolated from a themophilic anaerobic reactor. International Journal of Systematic and Evolutionary 
Microbiology. 2002;52:1361-1368. DOI: $10.1099 / 00207713-52-4-1361$

[146] Angelidaki I, Ellegaard L, Ahring BK. A mathematical model for dynamic simulation of anaerobic digestion of complex substrates: Focusing on ammonia inhibition. Biotechnology and Bioengineering. 1993;42:159-166

[147] Fontana A, Patrone V, Puglisi E, Morelli L, Bassi D, Garuti M, et al. Effects of geographic area, feedstock, temperature, and operating time on microbial communities of six full-scale biogas plants. Bioresource Technology. 2016;218:980-990. DOI: 10.1016/j. biortech.2016.07.058

[148] Yu D, Kurola JM, Lähde K, Kymäläinen M, Sinkkonen A, Romantschuk M. Biogas production and methanogenic archaeal community in mesophilic and thermophilic anaerobic co-digestion processes. Journal of Environmental Management. 2014;143:54-60. DOI: 10.1016/j. jenvman.2014.04.025

[149] Yin DM, Westerholm M, Qiao W, Bi SJ, Wandera SM, Fan R, et al. An explanation of the methanogenic pathway for methane production in anaerobic digestion of nitrogenrich materials under mesophilic and thermophilic conditions. Bioresource Technology. 2018;264:42-50. DOI: 10.1016/j.biortech.2018.05.062

[150] Zhao J, Westerholm M, Qiao W, Yin D, Bi S, Jiang M, et al. Impact of temperature and substrate concentration on degradation rates of acetate, propionate and hydrogen and their links to microbial community structure. Bioresource Technology. 2018;256:44-52. DOI: 10.1016/j. biortech.2018.01.150

[151] Bousková A, Dohányos M, Schmidt JE, Angelidaki I. Strategies for changing temperature from mesophilic to thermophilic conditions in anaerobic
CSTR reactors treating sewage sludge. Water Research. 2005;39:1481-1488. DOI: 10.1016/j.watres.2004.12.042

[152] Dinsdale RM, Hawkes FR, Hawkes DL. Comparision of mesophilic and thermophilic upflow anaerobic sludge blanket reactors treating instant coffee production wastewater. Water Research. 1997;31:163-169. DOI: 10.1016/ S0043-1354(96)00233-3

[153] Patinvoh RJ, Osadolor OA, Chandolias K, Horváth S, Taherzadeh MJ. Innovative pretreatment strategies for biogas production. Bioresource Technology. 2017;224:13-24. DOI: 10.1016/j.biortech.2016.11.083

[154] Noike T, Endo G, Chang JE, Yaguchi JI, Matsumoto JI.

Characteristics of carbohydrate degradation and the rate-limiting step in anaerobic digestion. Biotechnology and Bioengineering. 1985;27:1482-1489

[155] Kelessidis A, Stasinakis AS. Comparative study of the methods used for treatment and final disposal of sewage sludge in European countries. Waste Management. 2012;32:1186-1195. DOI: 10.1016/j.wasman.2012.01.012

[156] Rajesh Banu J, Kavitha S, Tamilarasan K. Modelling for anaerobic process. In: Purohit HJ, Kalia V, Vaidya A, Khardenavis A, editors. Optimization and Applicability of Bioprocesses. Singapore: Springer; 2017. pp. 283-304. DOI: 10.1007/978-981-10-6863-8_14

[157] Rajesh Banu J, Kavitha S. Various sludge pretreatments: Their impact on biogas generation. In: Singh L, Kalia VC, editors. Waste Biomass Management-A Holistic Approach. Cham: Springer; 2017. pp. 39-71. DOI: 10.1007/978-3-319-49595-8_3

[158] Kumari D, Singh R. Pretreatment of lignocellulosic wastes for biofuel production: A critical review. Renewable and Sustainable Energy Reviews. 
2018;90:877-891. DOI: 10.1016/j.

rser.2018.03.111

[159] Park SK, Jang HM, Ha JH, Park JM. Sequential sludge digestion after diverse pre-treatment conditions: sludge removal, methane production and microbial community changes. Bioresource Technology. 2014;162:331-340. DOI: 10.1016/j.biortech.2014.03.152

[160] Gagliano MC, Braguglia CM, Gianico A, Mininni G, Nakamura K, Rossetti S. Thermophilic anaerobic digestion of thermal pretreated sludge: Role of microbial community structure and correlation with process performances. Water Research. 2015;68:498-509. DOI: 10.1016/j. watres.2014.10.031

[161] Wong MT, Zhang D, Li J, Hui RKH, Tun HM, Brar MS, et al. Towards a metagenomic understanding on enhanced biomethane production from waste activated sludge after pH 10 pretreatment. Biotechnology for Biofuels. 2013;6:38. DOI: 10.1186/1754-6834-6-38

[162] Westerholm M, Crauwels S, Houtmeyers S, Meerbergen K, Van Geel M, Lievens B, et al. Microbial community dynamics linked to enhanced substrate availability and biogas production of electrokinetically pre-treated waste activated sludge. Bioresource Technology. 2016;218:

761-770. DOI: 10.1016/j.

biortech.2016.07.029

[163] Westerholm M, Crauwels S, Van Geel M, Dewil R, Lievens B, Appels L. Microwave and ultrasound pre-treatments influence microbial community structure and digester performance in anaerobic digestion of waste activated sludge. Applied Microbiology and Biotechnology. 2016;100:5339-5352. DOI: 10.1007/ s00253-016-7321-2
[164] Sanz JL, Rojas P, Morato A, Mendez L, Ballesteros M, GonzálesFernández C. Microbial communities of biomethanization digesters fed with raw and heat pre-treated microalgae biomasses. Chem. 2017;168:1013-1021. DOI: 10.1016/j. chemosphere.2016.10.109

[165] Xia Y, Yang C, Zhang T. Microbial effects of part-stream lowfrequency ultrasonic pretreatment on sludge anaerobic digestion as revealed by high-throughput sequencing-based metagenomics and metatranscriptomics. Biotechnology for Biofuels. 2018;11:47. DOI: 10.1186/ s13068-018-1042-y

[166] Wang TT, Sun ZY, Huang YL, Tan L, Tang YQ Kida K. Biogas production from distilled grain waste by thermophilic dry anaerobic digestion: Pretreatment of feedstock and dynamics of microbial community. Applied Biochemistry and Biotechnology. 2018;184:685-702. DOI: 10.1007/s12010-017-2557-6

[167] Monlau F, Sambusiti C, Barakat A, Quemeneur M, Trably E, Steyer JP, et al. Do furanic and phenolic compounds of lignocellulosic and algae biomass hydrolyzate inhibit anaerobic mixed cultures? A comprehensive review. Biotechnology Advances. 2014;32: 934-951. DOI: 10.1016/j. biotechadv.2014.04007

[168] Poirier S, Bize A, Bureau C, Bouchez T, Chapleur O. Community shifts within anaerobic digestion microbiota facing phenol inhibition: Towards early warning microbial indicators? Water Research. 2016;100:296-305. DOI: 10.1016/j. watres.2016.05.041

[169] Na JG, Lee MK, Yun YM, Moon C, Kim MS, Kim DH. Microbial community analysis of anaerobic granules in phenol-degrading UASB by next generation sequencing. 
Biochemical Engineering Journal. 2016;112:241-248. DOI: $10.1016 / j$. bej.2016.04.030

[170] Ozgun H, Dereli RK, Ersahin ME, Kinaci C, Spanjers H, van Lier JB. A review of anaerobic membrane bioreactors for municipal wastewater treatment: Integration options, limitations and expectations. Separation and Purification Technology. 2013;118:89104. DOI: 10.1016/j.seppur.2013.06.036

[171] Karadag D, Koroglu OE, Ozkaya B, Cakmakci M. A review on anaerobic biofilm reactors for the treatment of dairy industry wastewater. Process Biochemistry. 2015;50:262-271. DOI: 10.1016/j.procbio.2014.11.005

[172] Xu R, Yang Z-H, Zheng Y, Liu J-B, Xiong W-P, Zhang Y-R, et al. Organic loading rate and hydraulic retention time shape distinct ecological networks of anaerobic digestion related microbiome. Bioresource Technology. 2018;262:184-193. DOI: 10.1016/j. biortech.2018.04.083

[173] Bonk F, Popp D, Weinrich S, Straeuber H, Kleinsteuber S, Harms H, et al. Intermittent fasting for microbes: How discontinuous feeding increases functional stability in anaerobic digestion. Biotechnology for Biofuels. 2018;11:274. DOI: 10.1186/ s13068-018-1279-5

[174] Liu C, Li H, Zhang YY, Si DD, Chen QW. Evolution of microbial community along with increasing solid concentration during high-solids anaerobic digestion of sewage sludge. Bioresource Technology. 2016;216:8794. DOI: 10.1016/j.biortech.2016.05.048

[175] Liang X, Whitham JM, Holwerda EK, Shao X, Tian L, Wu Y-W, et al. Development and characterization of stable anaerobic thermophilic methanogenic microbiomes fermenting switchgrass at decreasing residence times. Biotechnology for Biofuels. 2018;11:243. DOI: 10.1186/ s13068-018-1238-1

[176] Dennehy C, Lawlor PG, Gardiner GE, Jiang Y, Cormican P, McCabe MS, et al. Process stability and microbial community composition in pig manure and food waste anaerobic co-digesters operated at low HRTs.

Frontiers of Environmental Science \& Engineering. 2017;11. DOI: $10.1007 /$ s11783-017-0923-9

[177] Tonanzi B, Gallipoli A, Gianico A, Montecchio D, Pagliaccia P, Di Carlo M, et al. Long-term anaerobic digestion of food waste at semi-pilot scale: Relationship between microbial community structure and process performances. Biomass and Bioenergy. 2018;118:55-64. DOI: 10.1016/j. biombioe.2018.08.001

[178] Martins AD, Ferreira BO, Ribeiro NC, Martins R, Leite LR, Oliveira G, et al. Metagenomic analysis and performance of a mesophilic anaerobic reactor treating food waste at various load rates. Environmental Technology. 2017;38:2153-2163. DOI: 10.1080/09593330.2016.1247197

[179] Moestedt J, Müller B, Westerholm M, Schnürer A. Ammonia threshold for inhibition of anaerobic digestion of thin stillage and the importance of organic loading rate. Microbial Biotechnology. 2016;9:180-194. DOI: 10.1111/1751-7915.12330

[180] Leite AF, Janke L, Lv ZP, Harms H, Richnow HH, Nikolausz M. Improved monitoring of semi-continuous anaerobic digestion of sugarcane waste: Effects of increasing organic loading rate on methanogenic community dynamics. International Journal of Molecular Sciences. 2015;16: 23210-23226. DOI: $10.3390 /$ ijms161023210 
[181] Hori T, Haruta S, Sasaki D, Hanajima D, Ueno Y, Ogata A, et al. Reorganization of the bacterial and archaeal populations associated with organic loading conditions in a thermophilic anaerobic digester. Journal of Bioscience and Bioengineering. 2015;119:337-344. DOI: 10.1016/j. jbiosc.2014.09.003

[182] Lerm S, Kleyboecker A, MiethlingGraff R, Alawi M, Kasina M, Liebrich $\mathrm{M}$, et al. Archaeal community composition affects the function of anaerobic co-digesters in response to organic overload. Waste Management. 2012;32:389-399. DOI: 10.1016/j. wasman.2011.11.013

[183] Ziels RM, Svensson BH, Sundberg C, Larsson M, Karlsson A, Yekta SS. Microbial rRNA gene expression and co-occurrence profiles associate with biokinetics and elemental composition in full-scale anaerobic digesters. Microbial Biotechnology. 2018;11:694-709. DOI: 10.1111/1751-7915.13264

[184] Xu R, Zhang K, Liu P, Khan A, Xiong J, Tian F, et al. A critical review on the interaction of substrate nutrient balance and microbial community structure and function in anaerobic co-digestion. Bioresource Technology. 2018;247:1119-1127. DOI: 10.1016/j. biortech.2017.09.095

[185] Sprott GD, Shaw KM, Jarell KF. Methanogenesis and the $\mathrm{K}^{+}$transport system are activated by divalent cations in ammonia-treated cells of Methanospirillum hungatei. The Journal of Biological Chemistry. 1985;260:9244-9250

[186] Sprott GD, Shaw KM, Jarell KF. Ammonia/potassium exchange in methanogenic bacteria. The Journal of Biological Chemistry. 1984;259:12602-12608

[187] Schnürer A, Nordberg A. Ammonia, a selective agent for methane production by syntrophic acetate oxidation at mesophilic temperature. Water Science and Technology. 2008;57:735-740. DOI: 10.2166/wst.2008.097

[188] Westerholm M, Dolfing J, Sherry A, Gray ND, Head IM, Schnürer A. Quantification of syntrophic acetate-oxidizing microbial communities in biogas processes. Environmental Microbiology Reports. 2011;3:500-505. DOI: 10.1111/j.1758-2229.2011.00249.x

[189] Westerholm M, Levén L, Schnürer A. Bioaugmentation of syntrophic acetate-oxidising culture in biogas reactors exposed to increasing levels of ammonia. Applied and Environmental Microbiology. 2012;78:7619-7625. DOI: 10.1128/AEM.01637-12

[190] Sun L, Müller B, Westerholm M, Schnürer A. Syntrophic acetate oxidation in industrial CSTR biogas digesters. Journal of Biotechnology. 2014;171:39-44. DOI: 10.1016/j. jbiotec.2013.11.016

[191] Lü F, Hao L, Guan D, Qi Y, Shao L, He P. Synergetic stress of acids and ammonium on the shift in the methanogenic pathways during thermophilic anaerobic digestion of organics. Water Research. 2013;47:2297-2306

[192] Fotidis IA, Karakashev D, Angelidaki I. The dominant acetate degradation pathway/methanogenic composition in full-scale anaerobic digesters operating under different ammonia levels. International Journal of Environmental Science and Technology. 2014;11: 2087-2094. DOI: 10.1007/ s13762-013-0407-9

[193] Werner JJ, Garcia ML, Perkins SD, Yarasheski KE, Smith SR, Muegge B, et al. Microbial community dynamics and stability during an ammoniainduced shift to syntrophic acetate oxidation. Applied and Environmental 
Microbiology. 2014;80:3375-3383. DOI: 10.1128/AEM.00166-14

[194] Hattori S, Kamagata Y, Hanada S, Shoun $\mathrm{H}$. Thermacetogenium phaeum gen. nov., sp. nov., a strictly anaerobic, thermophilic, syntrophic acetateoxidizing bacterium. International Journal of Systematic and Evolutionary Microbiology. 2000;50:1601-1609. DOI: 10.1099/00207713-50-4-1601

[195] Bhandari V, Gupta RS. Molecular signatures for the phylum (class)

Thermotogae and a proposal for its division into three orders (Thermotogales, Kosmotogales ord. nov. and Petrotogales ord. nov.) containing four families (Thermotogaceae, Fervidobacteriaceae fam. nov., Kosmotogaceae fam. nov. and Petrotogaceae fam. nov.) and a new genus Pseudothermotoga gen. nov. with five new combinations. Antonie Van Leeuwenhoek. 2014;105:143-168. DOI: 10.1007/s10482-013-0062-7

[196] Westerholm M, Roos S, Schnürer A. Tepidanaerobacter acetatoxydans $\mathrm{sp}$. nov., an anaerobic, syntrophic acetateoxidizing bacterium isolated from two ammonium-enriched mesophilic methanogenic processes. Systematic and Applied Microbiology. 2011;34:

260-266. DOI: 10.1016/j.

syapm.2010.11.018

[197] Schnürer A, Schink B, Svensson BH. Clostridium ultunense sp. nov., a mesophilic bacterium oxidizing acetate in syntrophic association with a hydrogenotrophic methanogenic bacterium. International Journal of Systematic Bacteriology. 1996;46:1145-1152

[198] Westerholm M, Roos S, Schnürer A. Syntrophaceticus schinkii gen. nov., sp. nov., an anaerobic, syntrophic acetate-oxidizing bacterium isolated from a mesophilic anaerobic filter. FEMS Microbiology Letters. 2010;309:100-104. DOI: 10.1111/j.1574-6968.2010.02023.x
[199] Karakashev D, Batstone DJ, Trably $\mathrm{E}$, Angelidaki I. Acetate oxidation is the dominant methanogenic pathway from acetate in the absence of Methanosaetaceae. Applied and Environmental Microbiology. 2006;72:5138-5141. DOI: 10.1128/AEM.00489-06

[200] Karlsson A, Einarsson P, Schnürer A, Eljertsson J, Svensson BH. Impact of trace element addition on degradation efficiency of volatile fatty acids, oleic acid and phenyl acetate and on microbial populations in a biogas digester. Journal of Bioscience and Bioengineering. 2012;114:446-452. DOI: 10.1016/j.jbiosc.2012.05.010

[201] Francisci DD, Kougias PG, Treu L, Campanaro S, Angelidaki I. Microbial diversity and dynamicity of biogas reactors due to radical changes of feedstock composition. Bioresource Technology. 2015;176:56-64. DOI: 10.1016/j.biortech.2014.10.126

[202] Bozan M, Akyol C, Ince O, Aydin S, Ince B. Application of next-generation sequencing methods for microbial monitoring of anaerobic digestion of lignocellulosic biomass. Applied Microbiology and Biotechnology. 2017;101:6849-6864. DOI: 10.1007/ s00253-017-8438-7

[203] Mu H, Zhao C, Zhao Y, Li Y, Hua D, Zhang X, et al. Enhanced methane production by semicontinuous mesophilic co-digestion of potato waste and cabbage waste: Performance and microbial characteristics analysis. Bioresource Technology. 2017;236:68-76. DOI: 10.1016/j.biortech.2017.03.138

[204] Zealand AM, Mei R, Papachristodoulou P, Roskilly AP, Liu WT, Graham DW. Microbial community composition and diversity in rice straw digestion bioreactors with and without dairy manure. Applied Microbiology and Biotechnology. 2018;102:8599-8612. DOI: $10.1007 / \mathrm{s} 00253-018-9243-7$ 
[205] Wang M, Zhou J, Yuan Y-X, Dai Y-M, Li D, Li Z-D, et al. Methane production characteristics and microbial community dynamics of mono-digestion and co-digestion using corn stalk and pig manure. International Journal of Hydrogen Energy. 2017;42:4893-4901. DOI: 10.1016/j. ijhydene.2016.10.144

[206] Li X, Liu YH, Zhang X, Ge CM, Piao RZ, Wang WD, et al. Evaluation of biogas production performance and dynamics of the microbial community in different straws. Journal of Microbiology and Biotechnology. 2017;27:524-534. DOI: $10.4014 / j m b .1608 .08062$

[207] Ozbayram EG, Kleinsteuber S, Nikolausz M, Ince B, Ince O.

Enrichment of lignocellulose-degrading microbial communities from natural and engineered methanogenic environments. Applied Microbiology and Biotechnology. 2018;102:1035-1043. DOI: $10.1007 / \mathrm{s} 00253-017-8632-7$

[208] Yu Q, Tian Z, Liu J, Zhou J, Yan Z, Yong $\mathrm{X}$, et al. Biogas production and microbial community dynamics during the anaerobic digestion of rice straw at $39-50^{\circ} \mathrm{C}$ : A pilot study. Energy \& Fuels. 2018;32:5157-5163. DOI: 10.1021/acs. energyfuels.7b04042

[209] Zhou J, Yang J, Yu Q, Yong X, Xie $X$, Zhang L, et al. Different organic loading rates on the biogas production during the anaerobic digestion of rice straw: A pilot study. Bioresource Technology. 2017;244:865-871. DOI: 10.1016/j.biortech.2017.07.146

[210] Ros M, JDS OF, Perez Murcia MD, Angeles Bustamante M, Moral R, Dolores Coll M, et al. Mesophilic anaerobic digestion of pig slurry and fruit and vegetable waste: Dissection of the microbial community structure. Journal of Cleaner Production. 2017;156:757-765. DOI: 10.1016/j. jclepro.2017.04.110
[211] Lu X, Rao S, Shen Z, Lee PKH.

Substrate induced emergence of differenct active bacterial and archaeal assemblages during biomethane production. Bioresource Technology. 2013;148:517-524. DOI: 10.1016/j. biortech.2013.09.017

[212] Grosser A, Neczaj E. Enhancement of biogas production from sewage sludge by addition of grease trap sludge. Energy Conversion and Management. 2016;125:301-308. DOI: 10.1016/j. enconman.2016.05.089

[213] Martinez EJ, Gil MV, Fernandez C, Rosas JG, Gomez X. Anaerobic codigestion of sludge: Addition of butcher's fat waste as a cosubstrate for increasing biogas production. PLoS One. 2016;11:e0153139. DOI: 10.1371/ journal.pone.0153139

[214] Zhu Z, Hsueh MK, He Q. Enhancing biomethanation of municipal waste sludge with grease trap waste as a co-substrate. Renewable Energy. 2011;36:1802-1807. DOI: 10.1016/j.renene.2010.11.014

[215] Ahlberg-Eliasson K, Nadeau E, Leven L, Schnurer A. Production efficiency of Swedish farm-scale biogas plants. Biomass and Bioenergy. 2017;97:27-37. DOI: 10.1016/j. biombioe.2016.12.002

[216] Amha YM, Sinha P, Lagman J, Gregori M, Smith AL. Elucidating microbial community adaptation to anaerobic co-digestion of fats, oils, and grease and food waste. Water Research. 2017;123:277-289. DOI: 10.1016/j. watres.2017.06.065

[217] Ziels RM, Beck DAC, Marti M, Gough HL, Stensel HD, Svensson BH. Monitoring the dynamics of syntrophic beta-oxidizing bacteria during anaerobic degradation of oleic acid by quantitative PCR. FEMS Microbiology Ecology. 2015;91:fiv028. DOI: $10.1093 /$ femsec/fiv028 
[218] Ziels RM, Beck DAC, Stensel HD. Long-chain fatty acid feeding frequency in anaerobic codigestionimpacts syntrophic community structure and biokinetics. Water Research. 2017;11:218-229. DOI: 10.1016/j. watres.2017.03.060

[219] Ning Z, Zhang H, Li W, Zhang R, Liu G, Chen C. Anaerobic digestion of lipid-rich swine slaughterhouse waste: Methane production performance, long-chain fatty acids profile and predominant microorganisms.

Bioresource Technology. 2018;269:426-433. DOI: 10.1016/j. biortech.2018.08.001

[220] Kougias PG, Treu L, Campanaro S, Zhu X, Angelidaki I. Dynamic functional characterization and phylogenetic changes due to Long Chain Fatty Acids pulses in biogas reactors. Science Reporter. 2016;6:28810. DOI: 10.1038/ srep28810

[221] Sousa DZ, Pereira A, Stams AJM, Alves MM, Smidt H. Microbial communities involved in anaerobic degradation of unsaturated or saturated long-chain fatty acids. Applied and Environmental Microbiology. 2007;73:1054-1064. DOI: 10.1128/ AEM.01723-06

[222] Baserba MG, Angelidaki I, Karakashev D. Effect of continuous oleate addition on microbial communities involved in anaerobic digestion process. Bioresource Technology. 2012;106:74-81. DOI: 10.1016/j.biortech.2011.12.020

[223] Shigematsu T, Tang Y, Mizuno Y, Kawaguchi H, Morimura S, Kida K. Microbial diversity of mesophilic methanogenic consortium that can degrade long-chain fatty acids in chemostat cultivation. Journal of Bioscience and Bioengineering. 2006;102:535-544. DOI: 10.1263/ jbb.102.535
[224] Yekta SS, Ziels RM, Bjorn A, Skyllberg U, Ejlertsson J, Karlsson A, et al. Importance of sulfide interaction with iron as regulator of the microbial community in biogas reactors and its effect on methanogenesis, volatile fatty acids turnover, and syntrophic longchain fatty acids degradation. Journal of Bioscience and Bioengineering. 2017;123:597-605. DOI: 10.1016/j. jbiosc.2016.12.003

[225] Regueiro L, Carballa M, Lema JM. Microbiome response to controlled shifts in ammonium and LCFA levels in co-digestion systems. Journal of Biotechnology. 2016;220:35-44. DOI: 10.1016/j.jbiotec.2016.01.006

[226] Razaviarani V, Buchanan ID. Anaerobic co-digestion of biodiesel waste glycerin with municipal wastewater sludge: Microbial community structure dynamics and reactor performance. Bioresource Technology. 2015;182:8-17. DOI: 10.1016/j.biortech.2015.01.095

[227] Jensen PD, Astals S, Lu Y, Devadas $\mathrm{M}$, Batstone DJ. Anaerobic codigestion of sewage sludge and glycerol, focusing on process kinetics, microbial dynamics and sludge dewaterability. Water Research. 2014;67:355-366. DOI: 10.1016/j.watres.2014.09.024

[228] Nga Thi D, Hatta K, Kwon SH, Rollon AP, Nakasaki K. Changes in the microbial community during the acclimation stages of the methane fermentation for the treatment of glycerol. Biomass and Bioenergy. 2014;68:240-249. DOI: 10.1016/j.biombioe.2014.06.022

[229] Treu L, Campanaro S, Kougias PG, Zhu X, Angelidaki I. Untangling the effect of fatty acid addition at species level revealed different transcriptional responses of the biogas microbial community members. Environmental Science \& Technology. 2016;50:6079-6090. DOI: 10.1021/acs.est.6b00296 
[230] Sousa DZ, Salvador AF, Ramos J, Guedes AP, Barbosa S, Stams AJM, et al. Activity and viability of methanogens in anaerobic digestion of unsaturated and saturated long-chain fatty acids. Applied and Environmental Microbiology. 2013;79:4239-4245. DOI: 10.1128/aem.00035-13

[231] Zhang C, Su H, Baeyens J, Tan T. Reviewing the anaerobic digestion of food waste for biogas production. Renewable and Sustainable Energy Reviews. 2014;38:383-392. DOI: 10.1016/j.rser.2014.05.038

[232] Moestedt J, Nordell E, Yekta SS, Lundgren J, Martí M, Sundberg C, et al. Effects of trace element addition on process stability during anaerobic co-digestion of OFMSW and slaughterhouse waste. Waste Management. 2015;47:11-20. DOI: 10.1016/j.wasman.2015.03.007

[233] Bayr S, Pakarinene O, Korppoo A, Liuksia S, Väisänen A, Kaparaju P, et al. Effect of additives on process stability of mesophilic anaerobic monodigestion of pig slaughterhouse waste. Bioresource Technology. 2012;120:106-113. DOI: 10.1016/j.biortech.2012.06.009

[234] Eftaxias A, Diamantis V, Aivasidis A. Anaerobic digestion of thermal pre-treated emulsified slaughterhouse wastes (TESW): Effect of trace element limitation on process efficiency and sludge metabolic properties. Waste Management. 2018;76:357-363. DOI: 10.1016/j.wasman.2018.02.032

[235] Lebuhn M, Liu F, Heuwinkel H, Gronauer A. Biogas production from mono-digestion of maize silage-longterm process stability and requirements. Water Science and Technology. 2008;58:1645-1651. DOI: 10.2166/ wst.2008.495

[236] Gustavsson J, Svensson BH, Karlsson A. The feasibility of trace element supplementation for stable operation of wheat stillage-fed biogas tank reactors. Water Science and Technology. 2011;64:320-325. DOI: 0273-1223

[237] Nordell E, Nilsson B, Nilsson Påledal S, Karisalmi K, Moestedt J. Co-digestion of manure and industrial waste-The effects of trace element addition. Waste Management. 2016;47:21-27. DOI: 10.1016/j. wasman.2015.02.032

[238] Molaey R, Bayrakdar A, Sürmeli RO, Calli B. Influence of trace element supplementation on anaerobic digestion ofchicken manure: Linking process stability to methanogenic population dynamics. Journal of Cleaner

Production. 2018;181:794-800

[239] Yekta SS, Svensson BH, Björn A, Skyllberg U. Thermodynamic modeling of iron and trace metal solubility and speciation under sulfidic and ferruginous conditions in full scale continuou stirred tank biogas reactors. Applied Geochemistry. 2014;47:61-73. DOI: 10.1016/j. apgeochem.2014.05.001

[240] Gustavsson J, Shakeri Yekta S, Sundberg C, Karlsson A, Eljertsson J, Skyllberg U, et al. Bioavailability of cobalt and nickel during anaerobic digestion of sulfur-rich stillage for biogas formation. Applied Energy. 2013;112:473-477. DOI: 10.1016/j.apenergy.2013.02.009

[241] Pham Minh T, Ketheesan B, Yan Z, Stuckey DC. Trace metal speciation and bioavailability in anaerobic digestion: A review. Biotechnology Advances. 2016;34:122-136. DOI: 10.1016/j. biotechadv.2015.12.006

[242] Speece RE. A survey of municipal anaerobic sludge digesters and diagnostic activity assays. Water Research. 1988;22:365-372. DOI: 10.1016/S0043-1354(88)90260-6 
[243] de Diego-Diaz B, Alejandro Cerdan JM, Javier Penas F, FernandezRodriguez J. Impact of supplementary nutrients on codigestion of agricultural waste: Study of temperatures. Food and Bioproducts Processing. 2018;110: 120-125. DOI: 10.1016/j.fbp.2018.05.003

[244] Hartmann T, Schwanhold N, Leimkuehler S. Assembly and catalysis of molybdenum or tungsten-containing formate dehydrogenases from bacteria. Biochimica et Biophysica Acta. 2015;1854:1090-1100. DOI: 10.1016/j. bbapap.2014.12.006

[245] Demirel B, Scherer P. Trace element requirements of agricultural biogas digesters during biological conversion of renewable biomass to methane. Biomass and Bioenergy. 2011;35:992-998. DOI: 10.1016/j.biombioe.2010.12.022

[246] Azim AA, Pruckner C, Kolar P, Taubner R-S, Fino D, Saracco G, et al. The physiology of trace elements in biological methane production. Bioresource Technology. 2017;241: 775-786. DOI: 10.1016/j.

biortech.2017.05.211

[247] Molaey R, Bayrakdar A, Sürmeli $\mathrm{RO}$, Calli B. Influence of trace element supplementation on anaerobic digestion of chicken manure: Linking process stability to methanogenic population dynamics. Journal of Cleaner Production. 2018;181:794-800. DOI: 10.1016/j.jclepro.2018.01.264

[248] Wintsche B, Jehmlich N, Popp D, Harms H, Kleinstauber S. Metabolic adaptation of methanogens in anaerobic digesters upon trace element limitation. Frontiers in Microbiology. 2018;9:405. DOI: 10.3389/ fmicb.2018.00405

[249] Neubeck A, Sjöberg S, Price A, Callac N, Schnürer A. Effect of nickel levels on hydrogen partial pressure and methane production in methanogens.
PLoS One. 2016;11:e0168357. DOI: 10.1371/journal.pone.0168357

[250] Nzila A. Mini review: Update on bioaugmentation in anaerobic processes for biogas production. Anaerobe. 2017;46:3-17. DOI: 10.1016/j. anaerobe.2016.11.007

[251] Öner BE, Akyol C, Bozan M, Ince $\mathrm{O}$, Aydin S, Ince B. Bioaugmentation with Clostridium thermocellum to enhance the anaerobic biodegradation of lignocellulosic agricultural residues. Bioresource Technology. 2018;249: 620-625. DOI: $10.1016 / \mathrm{j}$.

biortech.2017.10.040

[252] Speda J, Johansson MA, Odnell A, Karlsson M. Enhanced biomethane production rate and yield from lignocellulosic ensiled forage ley by in situ anaerobic digestion treatment with endogenous cellulolytic enzymes. Biotechnology for Biofuels. 2017;10: 129. DOI: 0.1186/ s13068-017-0814-0

[253] Peng X, Börner RA, Nges IA, Liu J. Impact of bioaugmentation on biochemical methane potential for wheat straw with addition of Clostridium cellulolyticum. Bioresource Technology. 2014;152:567-571. DOI: 10.1016/j.biortech.2013.11.067

[254] Zhang J, Guo R, Qiu Y, Qiao J, Yuan X, Shi X, et al. Bioaugmentation with an acetate-type fermentation bacterium Acetobacteroides hydrogenigenes improves methane production from corn straw. Bioresource Technology. 2015;179:306-313. DOI: 10.1016/j.biortech.2014.12.022

[255] Poszytek K, Ciezkowska M, Sklodowska A, Drewniak L. Microbial Consortium with High Cellulolytic Activity (MCHCA) for enhanced biogas production. Frontiers in Microbiology. 2016;7:324. DOI: 10.3389/fmicb.2016.00324 
[256] Odnell A, Recktenwald M, Stensén K, Jonsson B, Karlsson M. Activity, life time and effect of hydrolytic enzymes for enhanced biogas production from sludge anaerobic digestion. Water Research. 2016;103:462-471. DOI: 10.1016/j. watres.2016.07.064

[257] Azman S, Khadem AF, Plugge CM, Stams AJM, Bec S, Zeeman G. Effect of humic acid on anaerobic digestion of cellulose and xylan in completely stirred tank reactors: inhibitory effect, mitigation of the inhibition and the dynamics of the microbial communities. Applied Microbiology and Biotechnology. 2017;101:889-901. DOI: $10.1007 / \mathrm{s} 00253-016-8010-\mathrm{x}$

[258] Cirne DG, Paloumet X, Bjornsson L, Alves MM, Mattiasson B. Anaerobic digestion of lipid-rich waste-Effects of lipid concentration. Renewable Energy. 2007;32:965-975. DOI: 10.1016/j. renene.2006.04.003

[259] Silva SA, Cavaleiro AJ, Pereira MA, Stams AJM, Alves MM, Sousa DZ. Longterm acclimation of anaerobic sludges for high-rate methanogenesis from LCFA. Biomass and Bioenergy. 2014;67:297-303. DOI: 10.1016/j. biombioe.2014.05.012

[260] Sasaki K, Morita M, Sasaki D, Nagaoka J, Matsumoto N, POhmura N, et al. Syntrophic degradation of proteinaceous materials by the thermophilic strains Coprothermobacter proteolyticus and Methanothermobacter thermautotrophicus. Journal of Bioscience and Bioengineering. 2011;112:469-472. DOI: 10.1016/j. jbiosc.2011.07.003

[261] Fotidis IA, Karakashev D, Angelidaki I. Bioaugmentation with an acetate-oxidising consortium as a tool to tackle ammonia inhibition of anaerobic digestion. Bioresource Technology. 2013;146:57-62. DOI: 10.1016/j. biortech.2013.07.041
[262] Fotidis IA, Wang H, Fiedel N-R, Luo G, Karakashev DB.

Bioaugmentation as a solution to increase methane production from an ammonia-rich substrate. Environmental Science \& Technology. 2014;48:7669-7676. DOI: 10.1021/ es5017075
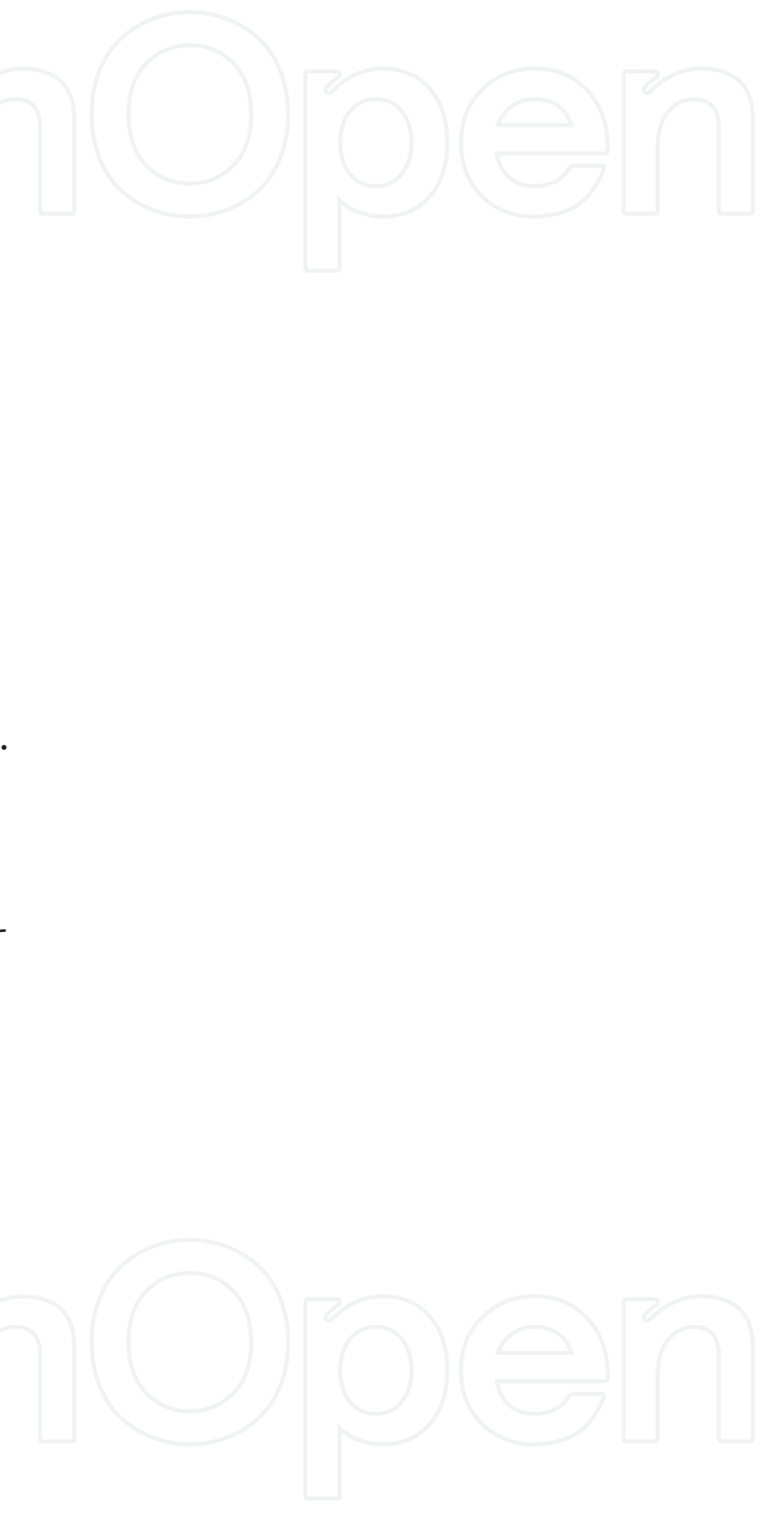